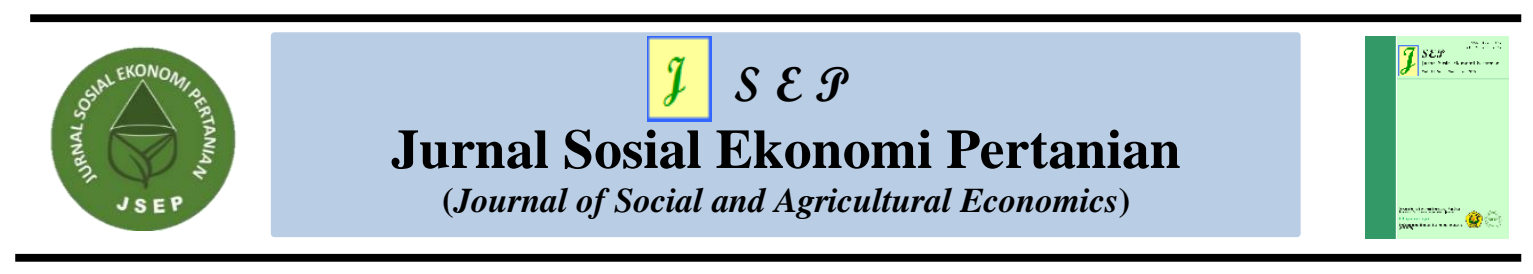

\title{
STRATEGI NAFKAH ISTRI NELAYAN BURUH DI DESA PENGAMBENGAN KECAMATAN NEGARA KABUPATEN JEMBRANA
}

\section{LIVELIHOOD STRATEGIES OF LABOR FISHERMEN'S WIVE IN PENGAMBENGAN VILLAGE DISTRICH OF NEGARA, JEMBRANA REGENCY, BALI PROVINCE}

\author{
Wilda Magfiroh ${ }^{1 *}$, Sofia $^{1}$ \\ ${ }^{1}$ Progam Studi Agribisnis, Fakultas Pertanian Universitas Jember \\ *email : wildamaghfiroh03@gmail.com
}

Naskah diterima: 30/01/2020 Naskah direvisi: 23/03/2020 Naskah diterbitkan: 31/03/2020

\begin{abstract}
Labor fishermen are the lowest element of social structure in the fishermen community. The unstable income of labor fishermen because of the season and weather conditions makes their wives work in the public sector to support their household income. This research aims to identify the motivation of the labor fishermen's wives to work in the public sector and to find out their livelihood strategies. The location of the research was determined purposively, namely Pengambengan_Village, Negara District, Jembrana Regency, Bali Province. This research used a descriptive and qualitative approach. The key informant was selected purposively while supporting informants were selected by using the snowball sampling technique. The data were collected by using methods of interview, observation and document were analyzed using the Miles and Huberman model. The results showed that 1) the motivation of the fishermen's wives to work in the public sector included physiological needs, safety needs, and social needs. 2) There were two livelihood strategies undertaken by labor fisherman wives, namely livelihood diversification through working as traders, tailors, and labor; migration through working outside the village as a laborer in the agricultural sector.
\end{abstract}

Keywords: Labor Fishermen's Wife, Motivation, Livelihood Strategy, Diversification, Migration

\begin{abstract}
ABSTRAK
Nelayan buruh merupakan unsur terendah dalam struktur sosial masyarakat nelayan. Penghasilan yang tidak pasti karena kondisi alam mendorong istri mereka untuk kerja di sektor publik untuk menambah pendapatan rumahtangga mereka. Penelitian ini bertujuan untuk mengidentifikasi motivasi istri nelayan buruh melakukan pekerjaan di sektor publik dan mengetahui strategi nafkah yang dilakukan. Lokasi penelitian ditentukan secara sengaja yaitu di Desa Pengambengan, Kecamatan Negara, Kabupaten Jembarana, Provinsi Bali. Penelitian ini merupakan penelitian deskriptif kualitatif. Informan kunci dipilih secara sengaja, sedangkan informan pendukung dipilih dengan teknik snowball sampling. Data dikumpulkan dengan metode wawancara, observasi dan studi dokumen. Analisis data menggunakan analisis model Miles and Huberman. Hasil penelitian menunjukkan bahwa (1) motivasi istri nelayan buruh melakukan pekerjaan disektor publik karena kebutuhan fisiologis, kebutuhan rasa aman, dan kebutuhan sosial. (2) Terdapat dua strategi nafkah yang dilakukan oleh istri nelayan buruh yaitu diversifikasi nafkah dengan melakukan pekerjaan sebagai buruh, pedagang, dan penjahit; migrasi yaitu melakukan pekerjaan di luar desa sebagai buruh di sektor pertanian.
\end{abstract}

Kata Kunci : Istri Nelayan Buruh, Motivasi, Strategi Nafkah, Diversifikasi Nafkah, Migrasi

How to Cite: Magfiroh, W., \& Sofia. (2020). Strategi Nafkah Istri Nelayan Buruh di Desa Pengambengan Kecamatan Negara Kabupaten Jembrana. JSEP: Jurnal Sosial Ekonomi Pertanian, 13(1): 73-91. 


\section{PENDAHULUAN}

Sektor perikanan memiliki peran yang sangat strategis dalam pembangunan nasional di Indonesia. Menurut Septiana (2017:01), potensi sumberdaya perikanan memiliki kontribusi yang sangat besar dalam mewujudkan progam pembangunan dan menunjang pertumbuhan perekonomian di Indonesia. Sumberdaya perikanan mampu memberikan kontribusi berupa peningkatan devisa negara, penyedia lapangan pekerjaan, penyedia bahan baku industri, peningkatan pendapatan nelayan, pengembangan sektor wisata dan pembangunan wilayah. Desa Pengambengan merupakan salah satu desa nelayan yang memiliki potensi cukup besar dalam sektor perikanan laut di Provinsi Bali, selain itu Desa Pengambengan juga memiliki Pelabuhan Perikanan terbesar di Provinsi Bali atau disebut dengan Pelabuhan Perikanan Nusantara (PPN) Pengambengan yang memiliki peran serta kontribusi yang sangat strategis dalam pembangunan perekonomian di wilayah pesisir Desa Pengambengan. Potensi tersebut dapat dilihat dari jumlah produksi atau tangkapan ikan pada sektor perikanan laut di Desa Pengambengan produksi perikanan tangkap di Desa Pengambengan berkisar antara 3.444 ton sampai dengan 18.048 ton per tahun. Jumlah produksi tertinggi terjadi pada tahun 2014 dengan total produksi sebesar 18.046 ton dan terendah terjadi pada tahun 2017 dengan hasil tangkapan sebesar 3.444 ton (Statistik PPN Pengambengan, 2017). Penurunan tersebut terjadi akibat musim paceklik yang berkepanjangan di Kawasan Pesisir Kecamatan Negara. Keadaan tersebut juga menyebabkan perekonomian nelayan di Desa Pengambengan mengalami penurunan, karena sebagian penduduk di Desa Pengambengan merupakan penduduk yang menggantungkan hidupnya sebagai nelayan.

Berdasarkan profil Desa Pengambengan Tahun 2017, menyebutkan bahwa jumlah penduduk yang berprofesi sebagai nelayan adalah sebanyak 2.932 orang dari 12.581 orang penduduk di Desa Pengambengan. Nelayan merupakan profesi yang telah menjadi bagian yang tidak dapat terpisahkan, karena menjadi nelayan merupakan strategi hidup yang ditempuh oleh masyarakat di Desa Pengambengan untuk mempertahankan hidup dan sebagai sumber dalam memperoleh nafkah dan penghasilan, namun sektor perikanan di Desa Pengambengan mengalami beberapa permasalahan dan ketimpangan yang disebabkan oleh berbagai faktor, baik faktor alamiah maupun faktor non alamiah. Kusnadi (2002: 202), menjelaskan faktor alamiah terkait dengan fluktuasi musim yang tidak dapat diprediksi, sedangkan faktor non alamiah berkaitan dengan ketimpangan dalam sistem bagi hasil. Permasalahan yang disebabkan oleh faktor alamiah berupa perubahan cuaca dan musim yang tidak dapat diprediksi. Perubahan cuaca dan musim tersebut dapat mempengaruhi hasil tangkapan ikan yang diperoleh nelayan. Hasil tangkapan ikan dan harga ikan juga akan berpengaruh terhadap hasil pendapatan yang diperoleh nelayan di Desa Pengambengan.

Pendapatan nelayan yang tidak dapat diprediksi karena sangat bergantung dengan kondisi alam, cuaca dan harga ikan hasil tangkapan akan berdampak pula pada nelayan buruh yang merupakan lapisan pekerja pada strata paling rendah dan sebagai lapisan sosial yang paling miskin (Kusnadi, 2002:3). Keterbatasan keterampilan serta ketergantungannya terhadap nelayan pemilik menjadi permasalahan dalam keberlanjutan nafkah rumah tangganya. Kondisi demikian mendorong istri-istri nelayan buruh harus lebih aktif dalam melakukan pekerjaan di sektor publik, yaitu dengan melakukan berbagai pekerjaan yang berkaitan dalam hal mencari nafkah dan mengikuti berbagai kegiatankegiatan sosial. Istri-istri nelayan buruh di Desa Pengambengan berusaha untuk lebih aktif dalam melakukan pekerjaan di sektor publik, namun mereka belum banyak terlibat dalam progam-progam pembangunan pesisir yang dicanangkan oleh pemerintah, seperti pelatihan atau penyuluhan baik dalam kegiatan ekonomi maupun kegiatan sosial. Aktivitas kegiatan ekonomi seperti mengolah hasil perikanan terutama ikan-ikan yang memiliki harga rendah, mereka belum memiliki pengetahuan serta tidak memiliki teknologi untuk mengolahnya.

Sumarti (2010: 210), menjelaskan dalam konteks relasi gender dapat dikemukakan bahwa kontruksi sosial budaya komunitas masyarakat setempat telah membentuk laki-laki dan perempuan memiliki aset, akses terhadap sumberdaya yang berbeda. Perempuan atau istri-istri nelayan di Desa Pengambengan tidak diperkenankan untuk melakukan kegiatan melaut karena resiko yang tinggi, hal ini dapat menyebabkan adanya diskriminasi akses dan alami subordinasi dalam hal akses terhadap sumberdaya produktif, sehingga istri-istri nelayan buruh memiliki keterbatasan dalam memanfaatkan sumberdaya yang produktif. Adanya sumberdaya yang tersedia di darat seperti ikan hasil tangkapan, relasi sosial, dan potensi wisata pesisir, harapannya mereka dapat memanfaatkanya secara lebih optimal untuk menciptakan berbagai strategi nafkah. Keterbatasan ekonomi menuntut istri nelayan buruh di Desa Pengambengan harus berperan lebih aktif dalam pekerjaan publik. Permasalahan 
tersebut juga didukung dengan perilaku masyarakat nelayan setempat yang memiliki gaya hidup tinggi atau konsumtif. Kondisi demikian akan menimbulkan permasalahan karena mereka juga memiliki keterbatasan dalam menciptakan mata pencaharian lainnya, sehingga dengan kondisi ekonomi yang demikian mendorong istri nelayan buruh di Desa Pengambengan harus menciptakan dan mencari nafkah tambahan.

Beberapa penelitian terdahulu telah mengkaji mengenai motivasi istri nelayan bekerja dan strategi nafkah istri nelayan, namun setiap daerah memiliki karakteristik dan ciri khas yang berbedabeda mengenai penelitian yang mengkaji topik tersebut. Hasil penelitian yang dilakukan oleh Badu (2015:7), yang berjudul Peranan Perempuan dalam meningkatkan Kesejahteraan Keluarga Nelayan di Desa Boyantongo Kecamatan Parigi Selatan Kabupaten Parigi Moutong mengkaji tentang motivasi kaum perempuan melakukan kegiatan di luar rumah (sektor publik) karena adanya dorongan untuk mencukupi kebutuhan rumah tangga, memanfaatkan keterampilan yang ia miliki dan adanya rasa tanggung jawab terhadap keluarga. Penelitian yang dilakukan oleh Laila (2015:65), dengan judul "Strategi Nafkah Perempuan Nelayan terhadap Pendapatan Keluarga" menjelaskan hasil bahwa strategi nafkah yang dilakukan oleh perempuan nelayan di Pesisir Sendang Biru meliputi: strategi pola nafkah ganda dan tunggal. Strategi nafkah lainnya yaitu dengan melakukan migrasi menjadi TKW di luar negeri. Sedangkan dalam penelitian ini lebih memfokuskan pada istri nelayan buruh dimana nelayan buruh merupakan nelayan yang bekerja pada perahu nelayan pemilik atau perahu milik orang lain dan nelayan buruh hanya dapat bekerja ketika perahu yang dimiliki nelayan pemilik melakukan kegiatan melaut. Penelitian ini terfokus pada hal tersebut karena penghasilan nelayan buruh bersifat tidak pasti dan memiliki pembagian hasil yang rendah, sehingga membutuhkan strategi nafkah lainnya untuk memenuhi kebutuhan hidup rumah tangga. Berdasarkan fakta tersebut peneliti mengkombinasikan masalah mengenai motivasi istri nelayan buruh melakukan pekerjaan di sektor publik dan strategi nafkah yang dilalukan oleh istri nelayan buruh. Penelitian yang mengkaji mengenai motivasi istri nelayan bekerja di sektor publik dan strategi nafkah istri nelayan buruh masih belum banyak dilakukan dibandingkan dengan motivasi istri dan strategi nafkah yang dilakukan di luar sektor perikanan seperti industri, perdagangan dan lain-lain. Penelitian mengenai motivasi istri nelayan buruh bekerja di sketor publik dan strategi nafkah istri nelayan buruh perlu dilakukan dan dikaji dengan tujuan agar dapat memberikan manfaat bagi rumah tangga nelayan buruh dalam memilih dan melakukan strategi nafkah.

Berdasarkan permasalahan tersebut, maka peneliti mengambil beberapa rumusan masalah, yaitu (1) Apa motivasi istri nelayan buruh di Desa Pengambengan Kecamatan Negara Kabupaten Jembrana melakukan pekerjaan di sektor publik, (2) Bagaimana strategi nafkah yang dilakukan oleh istri nelayan buruh di Desa Pengambengan Kecamatan Negara Kabupaten Jembrana. Tujuan dari penelitian ini adalah untuk mengidentifikasi motivasi istri nelayan buruh melakukan pekerjaan di sektor publik dan untuk mengetahui strategi nafkah yang dilakukan oleh istri nelayan buruh di Desa Pengambengan dalam mencukupi kebutuhan hidup rumah tangga.

\section{METODOLOGI PENELITIAN}

Penelitian ini dilakukan di Kecamatan Negara tepatnya di Desa Pengambengan yang ditentukan secara sengaja (purposive method) berdasarkan pada perimbangan bahwa Desa Pengambengan merupakan desa nelayan dan lokasi sentral kegiatan perikanan laut di Kabupaten Jembrana. Penelitian ini dilaksanakan selama 4 bulan yaitu dari bulan Maret akhir hingga pertengahan bulan Juli. Metode penelitian ini menggunakan metode penelitian deskriptif kualitatif. Informan kunci ditentukan dengan menggunakan metode purposive sampling yaitu Ketua Kelompok Wanita Nelayan "Tanjung Cemara" yang bernama Ibu Nasika dan informan dalam penelitian terdiri atas 17 informan yang merupakan istri nelayan buruh. Informan pendukung dalam penelitian ini ditentukan dengan menggunakan metode snowball sampling. Informan pendukung yang digunakan antara lain adalah Ketua Paguyuban Masyarakat Pesisir Lampu yaitu Bapak Naf'an yang mengetahui secara umum kehidupan masyarakat nelayan di Desa Pengambengan. Informan pendukung selanjutnya yaitu nelayan buruh yang bernama Bapak Poniman dan Bapak Haerozik selaku nelayan buruh perahu slerek, kemudian Bapak Husni dan Bapak Bohari selaku nelayan buruh perahu sampan, kemudia bapak Abdul Aziz selaku nelayan penginter atau juru mudi dan Bapak Samsul Hadi selaku nelayan juru panggung. Informan-informan pendukung tersebut dipilih sebagai informan pendukung karena berdasarkan pertimbangan bahwa 
mereka merupakan nelayan yang terlibat secara langsung dalam kegiatan melaut atau kegiatan penangkapan ikan di Desa Pengambengan.

Metode pengumpulan data dilakukan dengan menggunakan 3 (tiga) metode yaitu wawancara, observasi non prtisipan dan studi dokumen. Metode analisis data menggunakan analisis data interaktif Miles and Huberman yang terdiri atas tahapan yaitu pengumpulan data, reduksi data, penyajian data dan penarikan simpulan dan verifikasi. Uji keabsahan data dalam penelitian ini dilakukan dengan menggunakan triangulasi sumber dan triangulasi teknik. Triangulasi sumber data dilakukan pada istri nelayan buruh, nelayan buruh, dan Ketua Kelompok Wanita Nelayan, sedangkan triangulasi teknik dilakukan dengan mencari data-data yang dengan menggunakan teknik pengumpulan data yang berbeda-beda. Peneliti menggunakan metode pengumpulan data dengan teknik wawancara, observasi non partisipan, dan studi dokumen pada subjek penelitian secara serempak. Metode observasi non partisipan digunakan untuk melihat kondisi serta gambaran umum yang sebenarnya terjadi di lapang. Metode wawancara dilakukan untuk mencari dan menemukan jawaban-jawaban dari 18 subjek penelitian yang telah di wawancarai. Metode dokumen digunakan untuk memperkuat dan mendukung informasi serta keabsahan data yang telah diperoleh peneliti.

\section{HASIL DAN PEMBAHASAN}

\section{Gambaran Umum Aktivitas dan Kehidupan Nelayan Buruh di Desa Pengambengan}

Nelayan buruh merupakan nelayan yang tidak memiliki modal produksi hanya menyumbangkan jasa tenaganya untuk bekerja pada pemilik perahu. Nelayan buruh di Desa Pengambengan pada umumnya bekerja pada pemilik perahu yaitu perahu slerek. Data Pelabuhan Perikanan Nusantara Pengambengan menyebutkan bahwa pemilik Perahu Slerek di Desa Pengambengan pada tahun 2018 sebanyak 56 orang dengan jumlah nahkoda atau juru panggung sebanyak 54 orang. Masing-masing dari perahu tersebut memiliki jumlah anak buah kapal yang berbeda-beda yaitu antara 14-50 orang. Total keseluruhan dari jumlah anak buah kapal slerek yang terdapat di Desa Pengambengan adalah sebanyak 2.253 orang.

Perahu slerek merupakan perahu berpasangan yang terdiri atas perahu slerek atau perahu lakilaki dan perahu pembawa jaring atau perahu perempuan. Masing-masing perahu didalamnya terdapat beberapa pekerja atau nelayan buruh. Perahu slerek atau perahu laki-laki terdiri atas pekerja atau nelayan buruh yang bekerja sebagai tukang kemudi atau biasa dalam masyarakat setempat disebut dengan penginter, tukang tali yang bertugas sebagai penarik tali bagian ujung jaring dan penjaga mesin. Perahu perempuan atau perahu jaring terdiri atas pekerja atau nelayan buruh yang bekerja sebagai juru panggung yang berperan penting dalam menentukan keberadaan ikan, kemudi, penjaga mesin, tukang timah yang bertugas sebagai penebar dan penarik timah, pekerja atau orang yang menjaring ikan ketika perahu memperoleh ikan. Perahu Slerek dapat beroperasi atau melakukan kegiatan melaut jika jumlah nelayan buruh atau nelayan pekerja mencukupi. Umumnya jumlah anak buah dalam sepasang perahu slerek yaitu sebanyak antara 14-50 orang, jika anak buah belum mencukupi maka perahu tidak dapat melakukan operasi atau kegiatan melaut. Kegiatan melaut yang dilakukan oleh nelayan buruh di Desa Pengambengan adalah pukul 14.00 siang atau pukul 15.00 sore dan kembali lagi pada pagi hari sekitar pukul 03.00-08.00 pagi. Waktu pulang atau kembali ini dipengaruhi oleh hasil tangkapan ikan yang didapatkan oleh nelayan.

\section{Kondisi Geografis}

Desa Pengambengan merupakan salah satu desa yang terletak di Kecamatan Negara dengan luas wilayah sebesar 3.565,00 Ha. Desa Pengambengan memiliki topografi desa yang didominasi oleh wilayah dataran rendah dengan ketinggian wilayah yaitu $7 \mathrm{~m}$ di atas permukaan laut. Iklim yang berada di Desa Pengambengan merupakan iklim tropis dan keadaan angin bertiup sedang kecuali pada kondisi tertentu. Suhu rata-rata harian di Desa Pengambengan adalah sebesar $35{ }^{\circ} \mathrm{C}$. Secara administratif Desa Pengambengan berbatasan dengan beberapa desa yaitu:

$\begin{array}{ll}\text { Sebelah Utara } & \text { : Desa Tegal Badeng Barat } \\ \text { Sebelah Selatan } & \text { : Selat Bali } \\ \text { Sebelah Timur } & \text { : Lingkungan Awen, Kelurahan Lelateng } \\ \text { Sebelah Barat } & \text { : Selat Bali }\end{array}$

Desa Pengambengan merupakan desa yang termasuk ke dalam wilayah tepi pantai atau pesisir. Luas wilayah tepi pantai atau pesisir yang dimiliki oleh Desa Pengambengan adalah sebesar 98 Ha. 
Wilayah pesisir tersebut merupakan potensi yang cukup besar bagi pengembangan sektor perikanan, sehingga dengan adanya potensi tersebut masyarakat yang tinggal di Desa Pengambengan banyak yang melakukan kegiatan perekomian dengan memanfaatkan sumberdaya laut yang tersedia. Potensi tersebut juga didukung dengan adanya pelabuhan perikanan di Desa Pengambengan yaitu Pelabuhan Perikanan Nusantara (PPN) Pengambengan yang merupakan pelabuhan perikanan terbesar di Provinsi Bali. Berikut merupakan peta wilayah Desa Pengambengan:

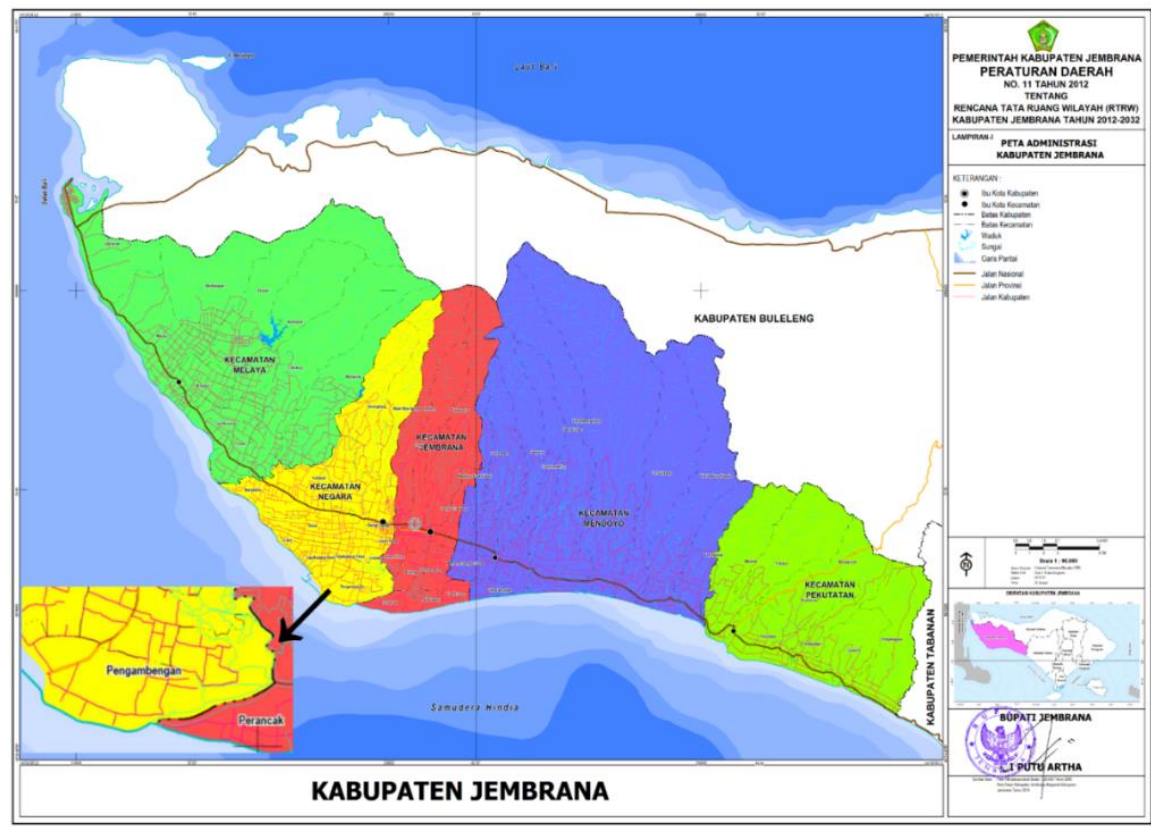

Sumber: Situs Resmi Pemerintahan Kabupaten Jembrana

\section{a. Daerah Tangkapan dan Lokasi Pelabuhan Perikanan}

Daerah tangkapan merupakan faktor yang sangat penting dalam menentukan keberadaan ikan. Ayodhyoa, (1981) dalam Pratiwi dkk. (2015) menjelaskan bahwa daerah penangkapan ikan merupakan suatu wilayah perairan tempat ikan berkumpul dan penangkapan ikan dapat dilakukan dengan baik dan wilayah tersebut memiliki karakteristik sebagai tempat untuk aktivitas penangkapan ikan. Berikut merupakan peta wilayah daerah penangkapan tangkapan ikan dan lokasi pelabuhan perikanan:

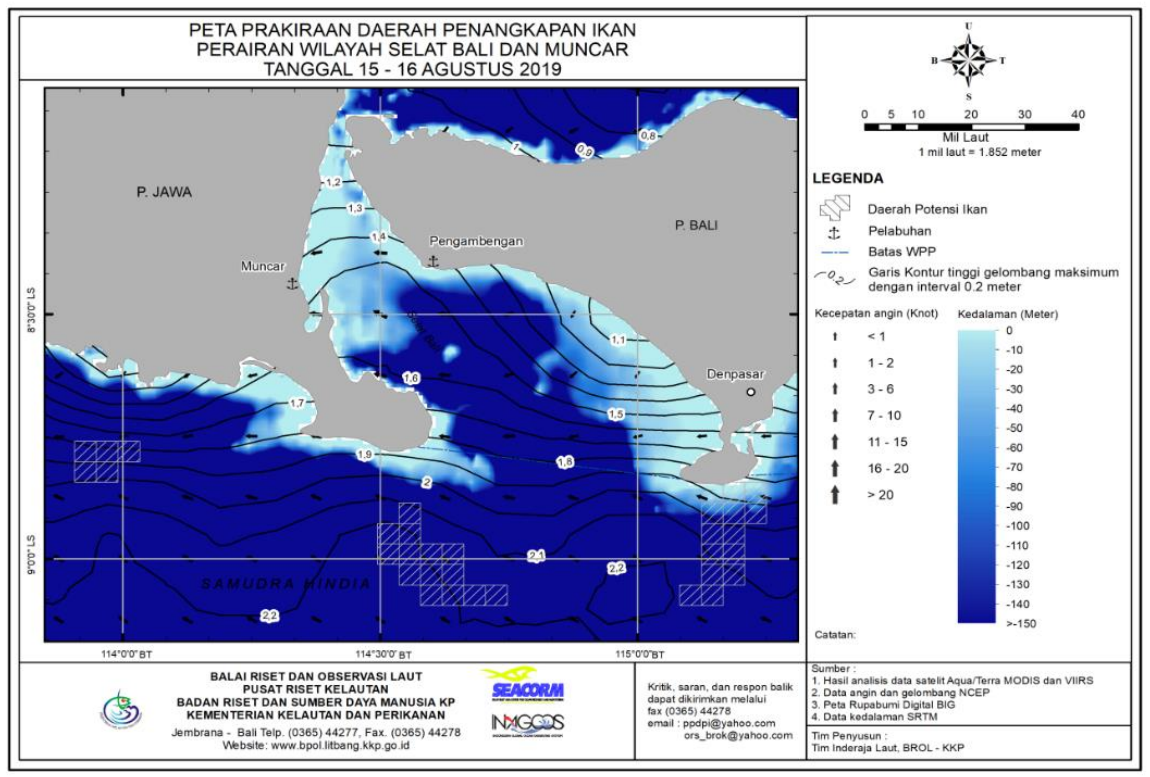

Sumber: Kementrian Kelautan dan Perikanan Republik Indonesia, 2020. 
Berdasarkan peta tersebut, dapat di ketahui bahwa potensi daerah tangkapan ikan terletak di perairan samudra hindia tepatnya di daerah perairan alas purwo dan perairan uluwatu. Potensi keberadaan ikan sangat dipengaruhi oleh musim dan cuaca sehingga keberadaan ikan bersifat tidak pasti. Letak Pelabuhan Perikanan Nusantara (PPN) Pengambengan berada tepat di Desa Pengambengan, dimana pelabuhan tersebut berfungsi sebagai tempat berkumpulnya kapal-kapal nelayan serta sebagai tempat untuk melakukan aktivitas kegiatan bongkar muat.

\section{Motivasi Istri Nelayan Buruh Bekerja di Sektor Publik}

Kusnadi dkk. (2006:47), mengatakan bahwa istri nelayan mengambil peran publik sebagai manifestasi dari tanggung jawab mereka menjaga kelangsungan hidup rumah tangganya. Pengaturan aktivitas domestik dan publik secara serasi telah memberikan kontribusi pada istri nelayan untuk memainkan peran yang optimal dalam kedudukannya sebagai istri, ibu anak-anak dan tiang ekonomi rumah tangga. Pekerjaan publik yang dilakukan istri-istri nelayan buruh merupakan alasan atau motivasi bagi istri nelayan buruh untuk menjaga eksistensi kelangsungan hidup rumah tangganya. Pengkajian mengenai motivasi istri nelayan buruh di Desa Pengambengan dalam melakukan pekerjaan di sektor publik, berdasarkan hasil analisis dari teori motivasi Hierarki Kebutuhan Maslow (1943), yaitu:

\section{a. Kebutuhan Fisiologis (Physiological Needs)}

Perempuan atau istri-istri nelayan buruh bekerja di sektor publik karena memiliki motivasi untuk memenuhi kebutuhan fisiologis. Menurut Maslow dalam Mangkunegara (2009:95), kebutuhan fisiologis merupakan kebutuhan untuk makan, minum, perlindungan fisik, bernapas, dan seksual. Kebutuhan fisiologis tersebut berkaitan dengan kebutuhan konsumsi berupa kebutuhan pangan dan sandang. Penghasilan suaminya sebagai nelayan yang bersifat tidak pasti, mendorong mereka untuk lebih giat dalam bekerja agar dapat mencukupi kebutuhan dasar dalam rumah tangganya yaitu kebutuhan untuk pangan. Motivasi bekerja tersebut merupakan suatu dorongan yang ingin dicapai untuk mempertahankan eksistensi kehidupannya agar tetap bisa hidup dan merasa aman atau tidak merasa kebingungan. Hal ini sesuai dengan yang diungkapkan oleh Peterson dan Plowman dalam Suwatno dan Priansa (2016:170), bahwa orang mau bekerja karena the desire to live yaitu keinginan untuk hidup yang merupakan keinginan utama dari setiap orang. Manusia bekerja untuk dapat makan dan untuk dapat melanjutkan kehidupannya.

Istri-istri nelayan buruh bekerja di sektor publik selain untuk memenuhi kebutuhan fisiologis, mereka juga bekerja untuk memenuhi kebutuhan materialnya. Kebutuhan material ini nantinya akan dimanfaatkan untuk menunjang dalam memenuhi kebutuhan fisiologis. Kebutuhan material adalah kebutuhan yang berkaitan dengan gaji atau upah berupa penghasilan tambahan. Motivasi tersebut merupakan dorongan yang memotivasi istri-istri nelayan buruh untuk melakukan pekerjaan karena kondisi perekonomian dalam rumah tangga nelayan buruh memiliki sifat yang tidak pasti dan sangat dipengaruhi oleh hasil tangkapan ikan yang didapatkan suami mereka. Menurut Kusnadi dkk. (2006:50), yang dimaksud tidak pasti adalah penghasilan yang diperoleh nelayan terkadang ada, sedangkan pada hari yang lain tidak ada sama sekali. Ketidakpatian tersebut diakibat adanya fluktuasi atau perubahan musim yang tidak dapat diprediksi. Perubahan musim tersebut menyebabkan nelayan buruh tidak dapat bekerja secara terus menerus. Kondisi tersebut mendorong istri-istri nelayan buruh harus bekerja untuk mencukupi kebutuhan hidup rumah tangganya.

\section{b. Kebutuhan Rasa Aman (Safety Needs)}

Goble (1971:73), menjelaskan bahwa kebutuhan rasa aman merupakan kebutuhan yang dapat dicapai setelah kebutuhan fisiologis terpuaskan. Kebutuhan rasa aman dimaksudkan untuk memenuhi kebutuhan akan perlindungan dari ancaman, bahaya, pertentangan dan lingkungan hidup, serta kebutuhan perlindungan mental, psikologikal dan intelektual juga diperlukan. Istri-istri nelayan buruh bekerja di sektor publik karena memiliki motivasi untuk berusaha memenuhi kebutuhan rasa aman terhadap kondisi perekonomian rumah tangganya. Istri nelayan buruh bekerja untuk memenuhi kebutuhan rasa aman atau safety needs terhadap dirinya dan kehidupan rumah tangganya agar tetap aman dan tidak kebingungan. Menurut Maslow (1943:376), seseorang yang tidak aman memiliki 
kebutuhan akan keteraturan dan stabilitas secara berlebihan serta akan berusaha keras untuk menghindari hal-hal yang memiliki sifat asing dan yang tidak diharapkan.

Istri nelayan buruh selain menjaga keteraturan kondisi ekonomi dalam rumah tangganya, mereka juga berusaha keras untuk mengantisipasi ancaman terhadap kondisi ekonomi rumah tangganya. Istri nelayan buruh berusaha untuk menyisihkan atau menabungkan sebagian dari penghasilannya, hal ini merupakan bentuk motivasi istri nelayan buruh untuk memenuhi rasa aman terhadap dirinya dan rumah tangganya. Kegiatan menabung atau saving perlu dilakukan karena mereka berjaga-jaga atau berusaha mengantisipasi untuk menghadapi masa yang akan datang khususnya ketika terjadi masa-masa sulit seperti ketika terjadi musim sepi ikan atau ketika suami mereka tidak melakukan kegiatan melaut sehingga tidak memperoleh penghasilan.

Istri-istri nelayan buruh juga harus bisa mengatur keuangan dalam rumah tangganya karena mereka memahami bahwa mereka tidak akan bergantung secara terus menerus kepada penghasilan suaminya. Hal tersebut sesuai dengan pernyataan Kadir (2016: 77), yaitu adapun usaha yang dilakukan oleh istri nelayan untuk membantu melangsungkan kehidupan sehari-hari yaitu dengan memaksimalkan pengelolaan keuangan misalnya menyisipkan penghasilan atau menghemat bahan makan guna mengurangi biaya atau pengeluaran. Penghematan juga dilakukan dengan menabung atau menyisipkan sedikit penghasilan mereka untuk kebutuhan yang bersifat mendadak serta untuk kebutuhan biaya pendidikan anak-anak.

\section{c. Kebutuhan Sosial (Social Needs)}

Maslow (1943:381) kebutuhan sosial adalah kebutuhan untuk merasa memiliki, yaitu kebutuhan untuk diterima dalam kelompok, berafiliasi, berinteraksi, dan kebutuhan untuk mencintai serta dicintai. Kusnadi dkk. (2006:42), memaparkan bahwa keterlibatan istri dalam kegiatan publik tidak hanya semata-mata untuk memenuhi kebutuhan ekonomi rumah tangga, tetapi juga untuk membangun status sosial di lingkungan masyarakatnya. Hubungan-hubungan sosial tersebut merupakan jembatan bagi mereka untuk memperoleh modal sosial yang bermanfaat guna menunjang dalam memperoleh sumber nafkah. Kegiatan-kegiatan sosial tersebut meliputi kegiatan arisan, gotong royong serta kegiatan keagamaan. Kegiatan-kegiatan tersebut merupakan sarana bagi mereka untuk dapat saling berbagi dan bertukar informasi.

Motivasi yang melatarbelakangi istri nelayan buruh melakukan pekerjaan di sektor publik adalah ingin mempererat hubungan sosial dengan tetangga-tetangganya. Kegiatan arisan merupakan kegiatan untuk berkumpul dengan teman-temannya guna menciptakan kehidupan yang rukun serta menjaga silaturahmi antar sesama. Selain itu, kegiatan arisan merupakan sarana sebagai tempat untuk menabung, sehingga dapat dimanfaatkan untuk kebutuhan di masa mendatang seperti yang dijelaskan oleh Rostiyati (2018:198), manfaat yang dirasakan dari kegiatan arisan adalah mereka dapat menabung dengan teratur dan bertukar pikiran dengan teman-teman yang juga mengikuti arisan. Kegiatan arisan lainya juga dilakukan dalam bentuk kegiatan arisan berupa barang. Manfaat yang diperoleh dengan mengikuti arisan barang adalah dapat membeli barang dengan cara mencicil dan tidak secara kontan atau langsung, karena membeli barang secara kontan terasa sangat berat. Istri-istri nelayan buruh juga mengatakan bahwa dengan mengikuti kegiatan arisan barang mereka mampu membeli barang-barang yang dibutuhkan dalam rumah tangganya. Hal ini selaras dengan pernyataan yang diungkapkan oleh Helmi dan Satria (2012:75), bahwa istri-istri nelayan kreatif dalam menciptakan pranata-pranata tradisional, seperti pembentukan kelompok arisan. Istri-istri nelayan buruh di Desa Pengambengan telah memanfaatkan pranata-pranata sosial tersebut untuk melakukan berbagai aktivitas sehingga dapat berfungsi ganda, yaitu dapat memperat hubungan sosial budaya dan membantu dalam mengatasi ketidakpastian penghasilan yang diperoleh suaminya.

Istri-istri nelayan buruh juga aktif melakukan kegiatan sosial lainnya yaitu kegiatan gotong royong. Kegiatan gotong royong ini mereka lakukan untuk menciptakan kerukunan dan memperkuat hubungan antar warga desa. Kegiatan gotong royong yang rutin dilakukan oleh warga di Desa Pengambengan adalah kegiatan gotong royong kerja bakti. Simanjuntak dkk. (1979:115), juga menjelaskan bahwa gotong royong kerja bakti merupakan sistem kerja sama dalam masyarakat yang dilakukan untuk suatu tujuan tertentu yang berguna bagi kepentingan umum. Kegiatan gotong royong kerja bakti dilakukan untuk membersihkan jalan, membersihkan pantai atau ngayah dan membersihkan tempat ibadah seperti masjid dan musholla. Kegiatan lainnya juga rutin dilaksanakan adalah kegiatan keagamaan, seperti kegiatan pengajian, menolong orang meninggal atau kifayah serta 
membantu warga ketika memiliki acara atau hajatan. Kusnadi (2002:52), menjelaskan bahwa istri nelayan kreatif menciptakan pranata-pranata tradisional, seperti pembentukan kelompok pengajian, simpan pinjam dan arisan. Kegiatan tersebut rutin dilaksanakan karena mereka menganggap pekerjaan itu sebagai perbuatan yang penting dilakukan dan mereka juga pasti akan mengalami keadaan yang sama.

\section{d. Kebutuhan akan Harga Diri atau Pengakuan (Esteem Needs)}

Esteem needs atau kebutuhan akan harga diri merupakan kebutuhan untuk dihormati dan dihargai oleh orang lain (Maslow, 1943: 381). Kebutuhan akan harga diri merupakan kebutuhan yang dapat dicapai setelah kebutuhan sosial terpenuhi, namun istri nelayan buruh di Desa Pengambengan belum mencapai atau mereka bekerja di sektor publik belum termotivasi untuk memenuhi kebutuhan penghargaan. Istri nelayan buruh di Desa Pengambengan bekerja di sektor publik memiliki hanya termotivasi untuk memenuhi kebutuhan fisiologis yang merupakan kebutuhan utama, kebutuhan rasa aman untuk mengantisipasi ketidakpastian penghasilan suami dan kebutuhan sosial. Kebutuhankebutuhan tersebut merupakan kebutuhan inti yang harus terpenuhi dalam kehidupan istri nelayan khususnya istri nelayan buruh.

\section{e. Kebutuhan Aktualisasi Diri (Self-Actualization Needs)}

Maslow (1943:382), mengatakan bahwa aktualisasi diri merupakan kebutuhan psikologis setiap orang untuk menumbuhkan, mengembangkan dan menggunakan kemampuannya. Istri-istri nelayan buruh di Desa Pengambengan bekerja di sektor publik belum mencapai atau mereka bekerja di sektor publik belum termotivasi atau terdorong untuk memenuhi aktualisasi diri. Istri-istri nelayan buruh di Desa Pengambengan melakukan pekerjaan di sektor publik hanya termotivasi atau terdorong untuk memenuhi kebutuhan inti saja yaitu berupa kebutuhan fisiologis, kebutuhan rasa aman dan kebutuhan sosial. Kebutuhan-kebutuhan tersebut perlu dipenuhi terlebih dahulu, karena kebutuhan tersebut adalah kebutuhan yang harus dicapai oleh istri nelayan buruh untuk mempertahankan eksistensi kehidupan rumah tangganya. Berikut merupakan matrik secara rinci mengenai motivasi istri nelayan buruh bekerja di sektor publik:

Tabel 2. Matrik Hasil dari Motivasi Istri Nelayan Buruh melakukan Pekerjaan di Sektor Publik

\begin{tabular}{|c|c|c|c|c|}
\hline \multirow{2}{*}{ Jenis Motivasi } & \multirow{2}{*}{$\begin{array}{l}\text { Fungsi dalam Mendukung } \\
\text { Penghidupan Keluarga }\end{array}$} & \multicolumn{3}{|c|}{ Kekuatan Motivasi } \\
\hline & & Kuat & Sedang & Lemah \\
\hline Kebutuhan Fisiologis & $\begin{array}{l}\text { Memenuhi kebutuhan pokok } \\
\text { terutama kebutuhan pangan } \\
\text { dan kebutuhan sehari-hari }\end{array}$ & $\checkmark$ & & \\
\hline Kebutuhan Rasa Aman & $\begin{array}{l}\text { Memenuhi kebutuhan } \\
\text { menabung dalam rumah } \\
\text { tangga untuk mengantisipasi } \\
\text { ketidakpastian penghasilan } \\
\text { yang diperoleh suami }\end{array}$ & $\checkmark$ & & \\
\hline Kebutuhan Sosial & $\begin{array}{l}\text { Memenuhi kebutuhan sosial } \\
\text { dengan masyarakat lainnya } \\
\text { seperti kerabat, kelompok } \\
\text { arisan dan pengajian, } \\
\text { paguyuban masyarakat } \\
\text { nelayan. }\end{array}$ & $\checkmark$ & & \\
\hline $\begin{array}{l}\text { Kebutuhan Akan Harga Diri } \\
\text { dan Penghargaan }\end{array}$ & - & & & \\
\hline Kebutuhan Aktualisasi Diri & - & & & \\
\hline
\end{tabular}

Sumber: Data Primer, 2019.

Berdasarkan matrik tersebut, dapat diketahui bahwa masing-masing dari jenis motivasi yang ingin di capai oleh istri nelayan buruh memiliki kekuatan yang tinggi. Kekuatan yang tinggi tersebut dikarenakan mereka bekerja di sektor publik untuk dapat memenuhi kebutuhan hidup yang harus 
tercukupi. Berdasarkan hasil wawancara dari 18 informan, mereka menyebutkan bahwa kebutuhan pokok seperti kebutuhan makan, kebutuhan dapur dan biaya untuk pendidikan anak-anak merupakan kebutuhan yang harus dapt dipenuhi setiap hari. Kondisi demikian mendorong dan memotivasi mereka untuk lebih giat untuk bekerja karena mereka juga tidak terus bergantung kepada penghasilan suaminya atau nelayan buruh. kebutuhan rasa aman juga merupakan motivasi yang cukup kuat untuk dicapai, karena kebutuhan menabung merupakan hal yang sangat penting bagi mereka sebagai simpanan atau tabungan yang dapat dimanfaatkan ketika terjadi musim paceklik atau tidak ada ikan. Kebutuhan sosial juga menjadi motivasi yang sangat kuat bagi istri nelyan buruh, karena mereka dapat menjalin hubungan sosial baik dengan kerabat, teman, kelompok arisan dan pengajian serta paguyuban masyarakat nelayan. Hubungan sosial tersebut akan memberikan bantuan kepada istri-istri nelayan buruh ketika sumberdaya terbatas, seperti kegiatan arisan yang merupakan sarana untuk kegiatan menabung.

\section{Strategi Nafkah Istri Nelayan Buruh di Desa Pengambengan}

\section{Sumber-sumber Nafkah Istri Nelayan Buruh di Desa Pengambengan}

Dharmawan (2007:182), memaparkan bahwa pemilihan strategi nafkah akan sangat ditentukan oleh rasionalisme yang dianut oleh aktor nafkah dalam memanfaatkan sumberdaya yang tersedia di lingkungan sekitarnya. Sumber-sumber nafkah merupakan aset atau modal yang digunakan oleh istriistri nelayan buruh untuk melakukan ragam strategi nafkah. Sumber nafkah terdiri atas beberapa sumber yang merupakan gabungan aset atau modal yang digabungkan untuk mengejar berbagai strategi nafkah atau matapencaharian. Penjelasan tersebut mengacu pada konsep strategi nafkah yang dikemukakan oleh Scoones (1998:7), bahwa kemampuan seseorang untuk mengejar strategi nafkah atau mata pencaharian yang berbeda-berbeda tergantung pada bahan atau materi dasar dan sosial serta aset terwujud dan tidak terwujud yang dimiliki oleh setiap manusia. Pengkajian mengenai sumbersumber nafkah atau sumber matapencaharian yang dimanfaatkan oleh istri nelayan buruh di Desa Pengambengan diidentifikasi berdasarkan konsep sumber nafkah yang dikemukakan oleh Scoones (1998:7-8), yaitu modal alam, modal ekonomi, modal manusia dan modal sosial. Keseluruhan modal tersebut merupakan modal yang digunakan sebagai kemampuan untuk mengejar strategi mata pencaharian. Berdasarkan hasil analisis lapang, terdapat 4 (empat) indikator yang teridentifikasi yaitu:

\section{a. Modal Alam}

Modal yang berasal dari alam dan dimanfaatkan dalam kehidupan sehari-hari disebut dengan modal sumberdaya alam. Modal alam merupakan modal yang sangat penting untuk memperoleh keseluruhan atau sebagian dari matapencaharian. Matapencaharian yang dimaksud adalah kegiatan yang berbasis sumberdaya seperti pertanian, perikanan, pengumpulan hasil hutan, dan ekstraksi mineral. Manfaat modal alam tidak sebatas itu saja, modal alam juga memiliki manfaat lain yang lebih penting yaitu sebagai sarana untuk bertahan hidup. Sarana tersebut berupa bantuan jasa lingkungan utama dan makanan yang dihasilkan dari modal alam. Jasa-jasa lingkungan tersebut adalah keanekaragaman hayati, peyerapan karbon, pengaturan air secara alamiah, keindahan alam dan udara yang bersih (DFID, 1999: 23). Berikut merupakan bagan secara rinci mengenai modal alam yang dimanfaatkan oleh istri-istri nelayan buruh di Desa Pengambengan:

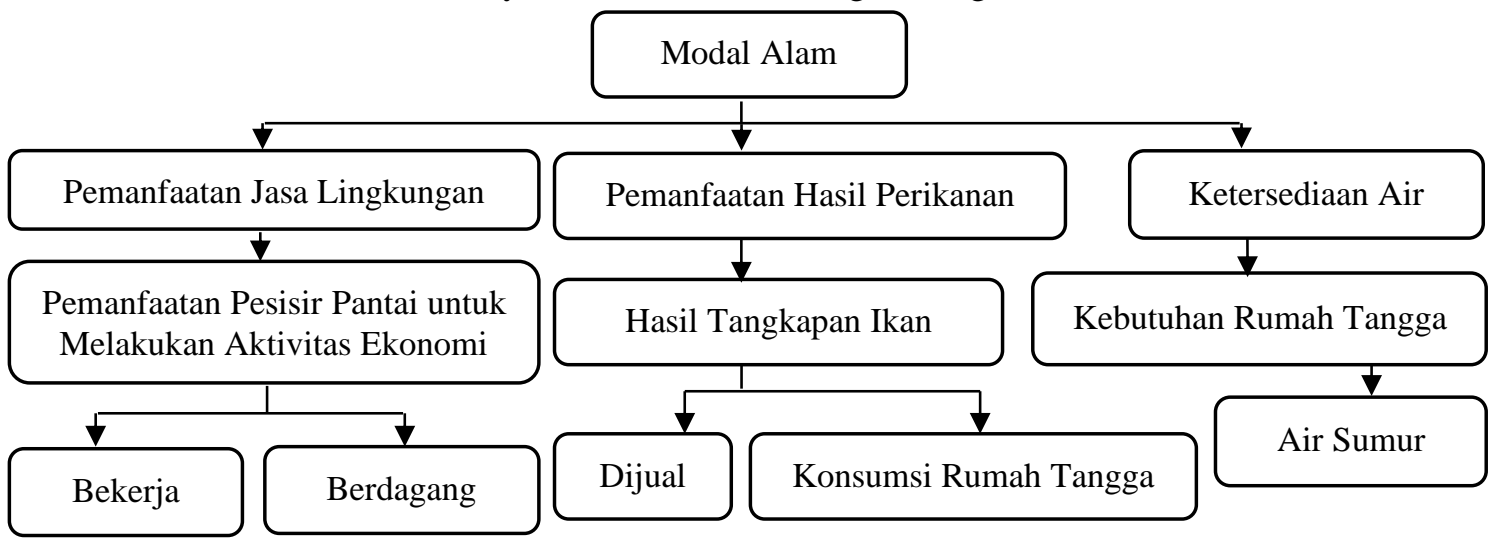

Gambar 1. Bagan Modal Alam Istri Nelayan Buruh di Desa Pengambengan 
Berdasarkan letak geografis Desa Pengambengan merupakan desa yang berada di wilayah pesisir pantai. Daerah desa yang berada di wilayah pesisir pantai memberikan keuntungan bagi istriistri nelayan buruh, karena sumberdaya alam tersebut dapat dikekola dan dimanfaatkan sebagai sumber matapencaharian. Modal alam tersebut berupa jasa lingkungan yaitu pesisir pantai yang dimanfaatkan sebagai sarana untuk melakukan berbagai pekerjaan. Pesisir pantai merupakan sumberdaya alam yang memiliki peran penting dalam menunjang nafkah rumah tangga nelayan buruh, karena istri-istri nelayan buruh melakukan aktivitas kegiatan perekonomian di pesisir pantai. Pesisir pantai dimanfaatkan oleh istri nelayan buruh untuk bekerja sebagai buruh. Pekerjaan sebagai buruh merupakan pekerjaan yang dilakukan untuk membantu nelayan sampan dalam aktivitas mendorong sampan dan membuka ikan dari jaring.

Sumber nafkah yang diperoleh dari bekerja dengan memanfaatkan pesisir pantai sebagai modal alam yaitu berasal dari hasil penjualan ikan yang diperoleh nelayan. Penghasilan yang diperoleh istri nelayan buruh juga bersifat tidak pasti, karena disesuaikan berdasarkan dari hasil penjualan dan perolehan ikan. Istri-istri nelayan buruh juga memanfaatkan hasil tangkapan ikan untuk konsumsi sebagai makanan sehari-hari. Istri nelayan buruh selain memanfaatkan hasil alam sebagai sumber mata pencaharian, mereka juga memanfaatkan jasa lingkungan berupa pesisir pantai untuk melakukan kegiatan perdagangan, seperti yang diungkapkan oleh Marini dan Ningsih (2015:55), bahwa jenis aktivitas ekonomi yang dilakukan oleh wanita nelayan adalah melakukan usaha dagang yaitu dengan berjualan di daerah pesisir pantai.

\section{b. Modal Ekonomi}

Modal ekonomi merupakan salah satu aset atau modal nafkah yang digunakan oleh istri-istri nelayan buruh untuk melakukan strategi nafkah. Mengacu pada konsep yang dikemukakan oleh Scoones (1998: 8), menurut hasil penelitian terdapat dua modal ekonomi yang dimanfaatkan oleh istri-istri nelayan buruh untuk melakukan berbagai strategi nafkah yaitu adanya ketersediaan finansial berupa uang tunai dan tabungan serta kepemilikan infrastruktur dasar. Modal-modal atau aset ekonomi tersebut digunakan oleh istri-istri nelayan buruh untuk menunjang kegiatan dalam mencari nafkah serta untuk memainkan pilihan-pilihan yang berguna bagi ketahanan hidup rumah tangganya. Berikut merupakan bagan secara rinci mengenai modal ekonomi yang dimanfaatkan oleh istri-istri nelayan buruh di Desa Pengambengan.

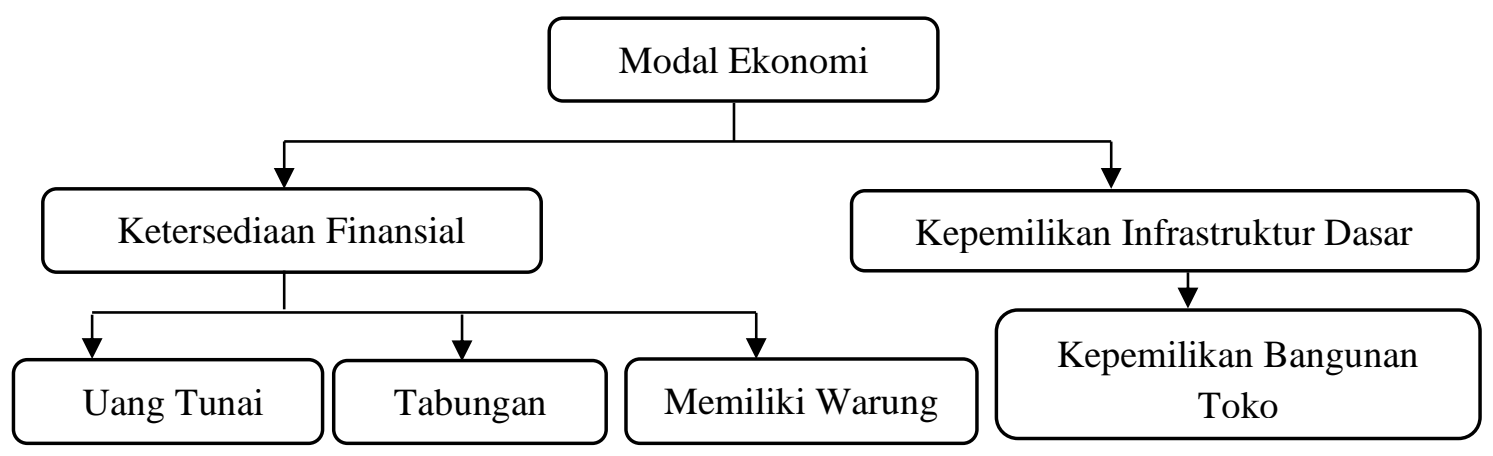

Gambar 2. Bagan Modal Ekonomi Istri Nelayan Buruh di Desa Pengambengan

Finansial atau keuangan merupakan salah satu aset atau modal ekonomi yang dimanfaatkan oleh istri-istri nelayan buruh di Desa Pengambengan untuk menunjang dalam aktivitas mencari nafkah. Ketersediaan finansial berupa uang tunai, merupakan modal yang harus tersedia karena uang merupakan aset yang dimanfaatkan setiap hari, baik untuk memenuhi kebutuhan hidup maupun digunakan sebagai modal untuk aktivitas mencari nafkah. Ketersediaan uang tersebut salah satunya dimanfaatkan untuk kegiatan berdagang. Uang tersebut digunakan sebagai modal untuk membuka warung di pinggir pantai sebagai alternatif usaha sampingan. Modal ekonomi berupa uang tersebut dikelola dan diatur sebaik mungkin agar dapat dimanfaatkan seterusnya walaupun keuntungan yang diperoleh dari hasil berdagang sedikit. Hasil dari kegiatan berdagang dapat dimanfaatkan sebagai sumber penghasilan untuk memenuhi kebutuhan rumah tangganya. Keuntungan yang diperoleh dari bekerja sebagai pedangan tidak dapat diketahui secara pasti, karena penghasilan yang diperoleh dari 
hasil jualan dimanfaatkan secara langsung untuk memenuhi kebutuhan sehari hari dan sisanya untuk ditabung dan dikumpulkan.

Ketersediaan finansial berupa uang juga dimanfaatkan oleh istri nelayan buruh sebagai modal untuk modal bekerja sebagai tukang sol sepatu. Bekerja menjadi tukang sol sepatu merupakan strategi nafkah yang dilakukan sebagai sumber penghasilan tambahan yang dapat dimanfaatkan untuk memenuhi kebutuhan hidup sehari hari. Istri-istri nelayan buruh sebagian besar banyak memanfaatkan modal ekonominya untuk menunjang dalam kegiatan mencari nafkah, namun hal ini berbeda dengan istri nelayan juru panggung. Adanya ketersediaan finansial berupa uang tunai akan disimpan dimanfaatkan untuk kebutuhan dimasa mendatang. Istri-istri nelayan khususnya nelayan juru panggung, mereka memiliki strategi yang berbeda dalam mengalokasikan ketersediaan finansial yang dimiliki. Istri-istri nelayan juru panggung di Desa Pengambengan tidak memanfaatkan modal ekonominya untuk melakukan pekerjaan, namun mereka lebih memilih untuk menabung serta mengelola penghasilan yang diperoleh suaminya. Modal nafkah berupa uang tunai dan tabungan dikumpulkan ketika suami mereka memperoleh penghasilan lebih banyak, sehingga ketika terjadi musim paceklik atau terjadi musim angin, mereka akan memanfaatkan tabungan tersebut untuk memenuhi kebutuhan sehari-hari. Sebagian besar istri-istri nelayan juru panggung di Desa Pengambengan tidak bekerja, karena mereka memiliki sumberdaya finansial yang mencukupi, seperti yang dipaparkan pada hasil penelitian Hamdani dan Wulandari (2016: 63), pada umumnya masyarakat nelayan kaya atau juragan memiliki penghasilan diatas rata-rata nelayan tradisional.

Istri nelayan buruh juga memiliki modal ekonomi berupa kepemilikan infrastruktur dasar. Infrastruktur dasar yang dimiliki oleh istri-istri nelayan buruh di Desa Pengambengan berupa infrastruktur fisik yaitu bangunan toko yang digunakan sebagai sarana untuk melakukan kegiatan perdagangan. Toko tersebut merupakan sumber nafkah yang dimanfaatkan sebagai sarana untuk menjual berbagai jajanan anak-anak serta kebutuhan rumah tangga seperti sembako, sabun cuci, sandal jepit dan barang-barang lainnya. Keberadaan infrastruktur fisik berupa bangunan toko merupakan salah satu modal ekonomi yang dapat dimanfaatkan oleh istri-istri nelayan buruh untuk mencapai strategi nafkah yang diinginkan, seperti penjelasan Kusnadi dkk. (2006: 36) dalam hasil penelitiannya yaitu jika istri nelayan memiliki modal yang cukup, maka mereka dapat mengembangkan usaha ekonomi secara mandiri, namun jika tidak maka istri-istri nelayan akan bekerja sebagai tenaga kerja lepas atau buruh pada unit usaha ekonomi milik orang lain.

\section{c. Modal Manusia}

Aset atau modal terpenting dalam pencapaian strategi nafkah adalah modal manusia. Berdasarkan hasil penelitian, terdapat 3 (tiga) aspek modal manusia yang dimanfaatkan oleh istri nelayan buruh di Desa Pengambengan. Keempat aspek tersebut sesuai dengan konsep yang dikemukakan oleh Scoones (1998:8), yaitu (1) keterampilan atau skills, (3) kesehatan, dan (4) kemampuan fisik. Berikut merupakan bagan secara rinci mengenai modal manusia yang dimanfaatkan oleh istri-istri nelayan buruh di Desa Pengambengan:

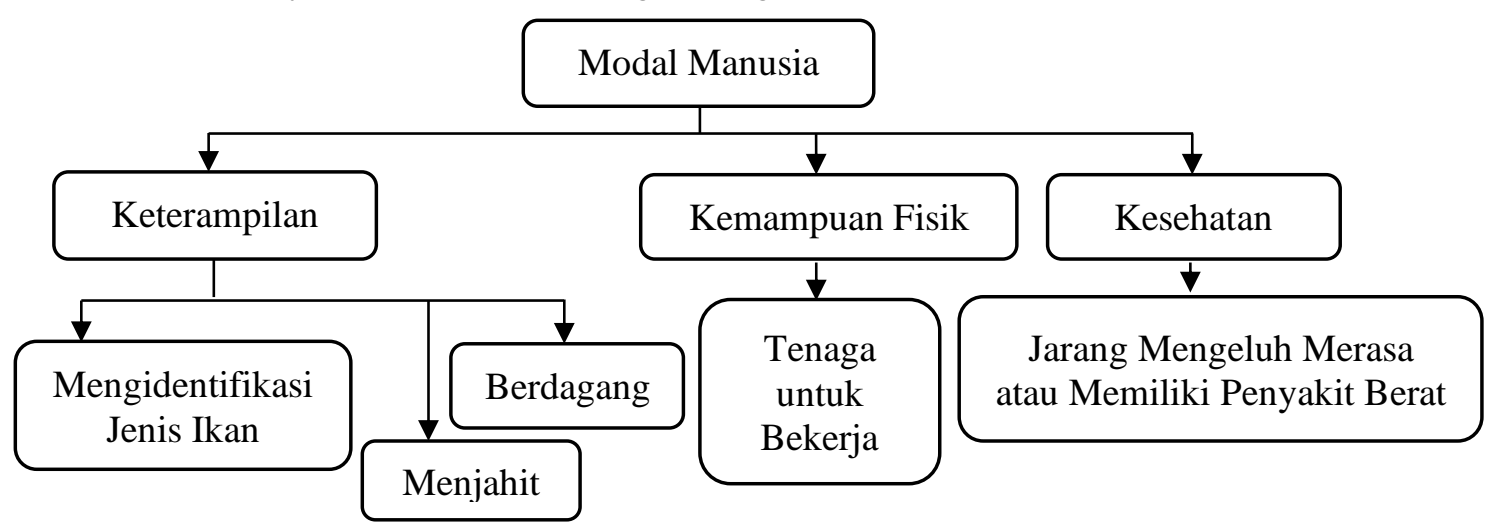

Gambar 3. Bagan Modal Manusia Istri Nelayan Buruh di Desa Pengambengan

Purnawanto (2010:91), keterampilan adalah perilaku yang menunjukkan kemampuan individu dalam melakukan tugas mental atau fisik tertentu yang dapat diobservasi. Tercapainya strategi nafkah tentunya memerlukan suatu modal manusia berupa keterampilan. Istri-istri nelayan buruh 
memanfaatkan keterampilan tersebut sebagai modal untuk bekerja sebagai buruh di pedagang ikan dan buruh di pabrik ikan. Mengidentifikasi atau breeding jenis-jenis ikan dan mengemas ikan merupakan salah satu keterampilan yang dimiliki oleh istri-istri nelayan buruh, selain itu istri-istri nelayan buruh juga memiliki keterampilan dalam menggunting atau memotong ikan, sehingga mereka memanfaatkan keterampilan tersebut untuk bekerja di pabrik ikan sebagai karyawan pada bagian cutting. Keterampilan yang dimiliki oleh istri-istri nelayan buruh tidak hanya sebatas dalam kegiatan mengurus ikan saja, namun istri-istri nelayan buruh juga memanfaatkan keterampilannya untuk kegiatan perdagangan dan menjahit.

Robbins dan Judge (2008:61), mendefinisikan kemampuan fisik (physical abilities) dapat diartikan sebagai modal manusia yang dimanfaatkan untuk keberhasilan pekerjaan yang kurang membutuhkan keterampilan dan lebih standar. Kemampuan fisik berupa tenaga dimanfaatkan oleh istri nelayan buruh untuk bekerja sebagai buruh di pantai yang berkaitan dengan aktivitas mendorong sampan ke laut dan ke darat, selain itu mereka juga bekerja untuk membuka atau memisahkan ikan dari jaring, membersihkan jaring dan memperbaiki jaring-jaring yang rusak. Pekerjaan yang membutuhkan modal tenaga tidak hanya dibutuhkan untuk pekerjaan sebagai buruh di pantai, tenaga juga dibutuhkan oleh istri-istri nelayan buruh untuk bekerja sebagai buruh di pabrik ikan. Pekerjaan menjadi buruh di pabrik membutuhkan tenaga serta pengetahuan agar dapat bekerja setiap hari.

Kesehatan juga merupakan salah satu faktor penting yang dimiliki oleh setiap manusia, karena kondisi kesehatan menentukan kualitas sumberdaya manusia. Menurut Wisana (2001:45), kesehatan mempengaruhi keadaan fisik pekerja dan produksi yang dihasilkan, sehingga seseorang dapat bekerja dengan kondisi kesehatan yang terjaga. Kualitas sumberdaya manusia khususnya kondisi fisik yang sehat sangat diperlukan dalam pencapaian strategi nafkah atau mata pencaharian. Kondisi kesehatan yang baik akan memudahkan setiap orang untuk melakukan pekerjaan. Istri nelayan buruh di Desa Pengambengan jarang untuk mengeluh merasa sakit atau memiliki penyakit berat, sehingga memiliki kondisi fisik yang memadai untuk bekerja. Kondisi fisik yang sehat mendorong istri nelayan buruh untuk terus giat bekerja.

\section{d. Modal Sosial}

Kimbal (2015: 54), modal sosial adalah sumberdaya sosial yang dapat dipandang sebagai investasi untuk mendapatkan sumberdaya yang baru demi mendatangkan keuntungan. Berdasarkan hasil penelitian, terdapat 3 (tiga) aspek modal sosial yang dimanfaatkan oleh istri nelayan buruh di Desa Pengambengan. Ketiga aspek tersebut sesuai dengan konsep yang dikemukakan oleh Scoones (1998: 8), yaitu (1) hubungan sosial, (2) jaringan kerja dan (3) asosiasi.

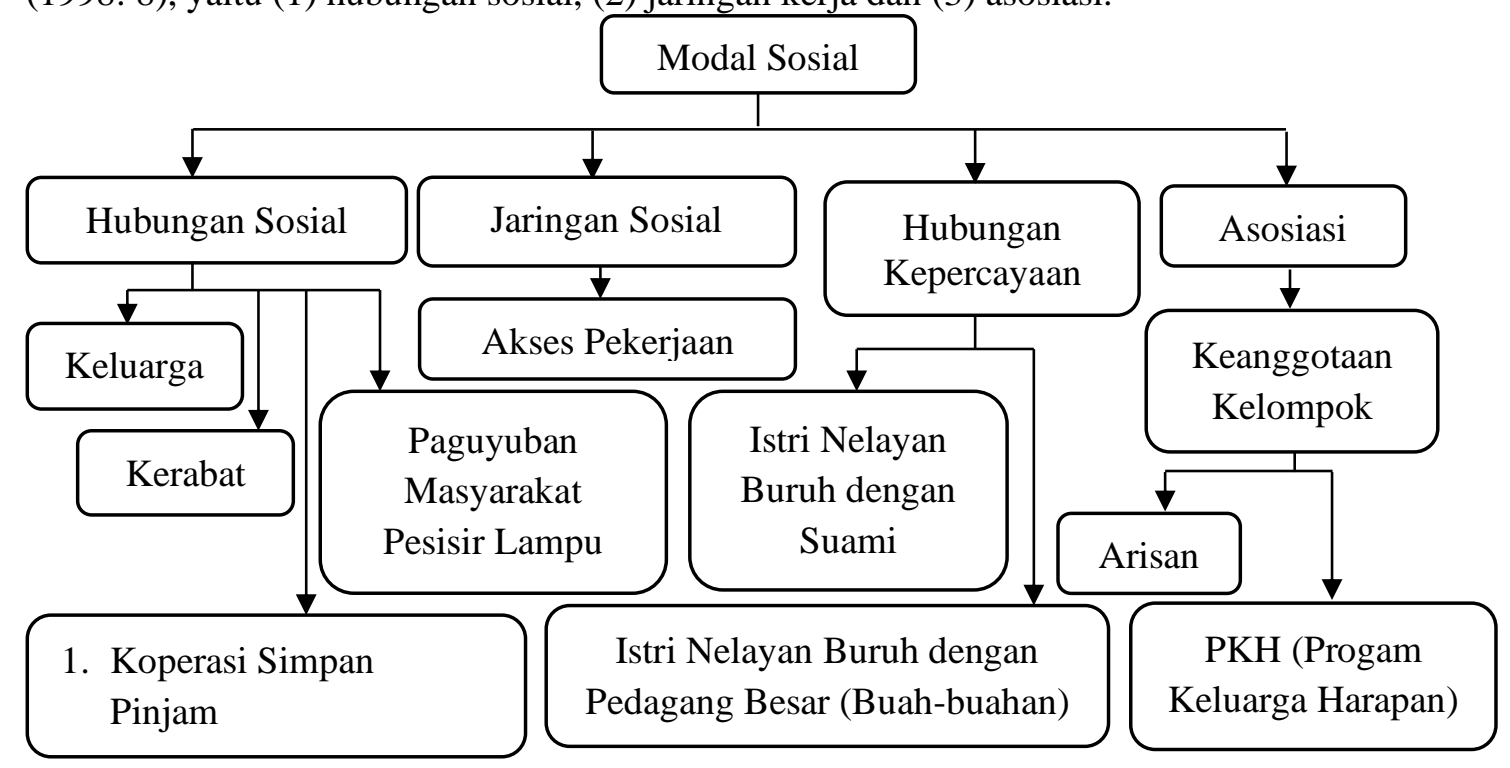

Gambar 4. Bagan Modal Sosial Istri Nelayan Buruh di Desa Pengambengan

Hubungan sosial dimanfaatkan oleh istri nelayan buruh sebagai salah satu strategi untuk menghadapi tekanan ekonomi ketika mereka kesulitan mendapatkan sumber daya ekonomi. Hubungan sosial tersebut dilakukan untuk berinteraksi dengan keluarga, kerabat, lembaga keuangan seperti koperasi dan bank serta dengan kelompok masyarakat atau paguyuban. Adanya hubungan 
sosial tersebut dapat dimanfaatkan oleh istri nelayan buruh untuk melakukan peminjaman uang ketika terjadi masa-masa sulit atau ketika musim paceklik. Meminjam uang kepada saudara merupakan strategi paling mudah yang dilakukan oleh istri nelayan buruh.

Istri-istri nelayan buruh melakukan peminjaman uang kepada lembaga keuangan seperti bank untuk memenuhi keperluan biaya membeli kendaraan bermotor serta untuk memenuhi kebutuhan biaya pendidikan anaknya. Peminjaman uang kepada lembaga keuangan seperti bank hanya dilakukan ketika membutuhkan biaya yang cukup besar, sedangkan untuk mencukupi kebutuhan sehari-hari mereka hanya melakukan peminjaman uang kepada saudara atau kerabatnya saja. Hal ini sesuai dengan yang dijelaskan oleh Kusnadi dkk. (2006:67), bahwa istri nelayan tidak hanya cerdik dalam mengelola keuangan berupa aset sumberdaya ekonomi rumah tangga, tetapi istri-istri nelayan juga memiliki tanggung jawab terhadap kondisi perekonomian dalam rumah tangga. Misalnya keadaan ketika terjadi musim paceklik, masa terang bulan ataupun ketika terdapat kebutuhan yang bersifat mendadak, dalam kondisi-kondisi sulit tersebut istri nelayan akan mencari pinjaman ke kerabat, tetangga, teman ataupun rentenir.

Kusnadi (2002: 23), mendefinisikan bahwa jaringan sosial merupakan hubungan-hubungan sosial timbal balik yang berbasis ikatan kekerabatan, ketetanggaan dan pertemanan. Manfaat dari adanya jaringan sosial adalah dapat mempermudah seseorang untuk memperoleh akses sumberdaya baik berupa uang, barang ataupun jasa melalui pertukaran timbal balik diantara anggota-anggotanya. Jaringan sosial memberikan manfaat untuk istri-istri nelayan buruh dalam memperoleh akses pekerjaan di sekitar tempat tinggalnya, seperti pekerjaan menjadi buruh di pantai dan berbagai pekerjaan lainnya yang dapat dilakukan oleh istri-istri nelayan buruh untuk memperoleh penghasilan yang halal. Jaringan sosial pada umumnya dibentuk atas dasar unsur kepercayaan atau trust. Kepercayaan yang dibangun oleh istri-istri nelayan buruh merupakan salah satu bentuk kepercayaan antara manusia dengan manusia. Menurut Granovetter (1985: 490), tindakan ekonomi seperti kegiatan jual beli selalu berkaitan dengan hubungan-hubungan sosial. Hubungan-hubungan sosial ini nantinya akan membentuk jaringan sosial yang akan menghasilkan trust atau kepercayaan dan mencegah terjadinya penyimpangan atau malfeasance yang dilakukan oleh pelaku ekonomi.

Istri-istri nelayan buruh juga memanfaatkan modal sosial dengan bergabung dalam keanggotaan kelompok atau asosiasi. Asosiasi tersebut dilakukan dengan berpartisipasi dalam keanggotaan kelompok yang meliputi kelompok arisan dan kelompok PKH (Progam Keluarga Harapan). Terdapat dua macam kegiatan arisan yang diikuti oleh istri-istri nelayan buruh di Desa Pengambengan yaitu arisan uang dan arisan barang. Arisan berupa uang biasanya dilakukan dalam kegiatan pengajian yang dilakukan setiap satu minggu sekali. Kegiatan arisan dalam bentuk uang ditujukan sebagai sarana untuk menabung atau menyimpan uang, sedangkan kegiatan arisan berupa barang ditujukan untuk membeli barang-barang kebutuhan rumah tangga dengan cara mencicil. Kegiatan arisan barang juga ditujukan untuk membeli keperluan barang yang akan diberikan kepada orang yang memiliki hajatan seperti acara pernikahan dan sunatan.

\section{Strategi Nafkah yang Dilakukan oleh Istri Nelayan Buruh di Desa Pengambengan}

Dharmawan (2007:185), menjelaskan bahwa dalam sosiologi nafkah, pengertian strategi nafkah lebih mengarah pada pengertian livelihood strategy atau strategi penghidupan dari pada means of living strategy (strategi cara hidup). Pengertian livelihood strategy yang disamakan pengertiannya menjadi strategi nafkah dalam bahasa Indonesia sebenarnya diartikan lebih besar dari pada sekedar "aktivitas mencari nafkah" belaka. Sebagai strategi membangun sistem penghidupan, maka strategi nafkah dapat didekati melalui berbagai cara atau manipulasi aksi individual maupun kolektif. Strategi nafkah bisa berarti cara bertahan hidup ataupun memperbaiki status kehidupan. Strategi nafkah adalah taktik dan aksi yang dibangun oleh individu ataupun kelompok dalam rangka mempertahankan kehidupan mereka dengan tetap memperhatikan eksistensi infrastruktur sosial, struktur sosial dan sistem budaya yang berlaku. Pengkajian mengenai strategi nafkah yang dilakukan oleh istri nelayan buruh di Desa Pengambengan diidentifikasi berdasarkan teori strategi nafkah yang dikemukakan oleh Scoones (1998: 9), yaitu:

\section{a. Intensifikasi dan Ekstensifikasi Pertanian}

Satria (2015:20), menyatakan bahwa aktivitas ekonomi perempuan merupakan gejala yang sudah umum bagi kalangan masyarakat pesisir, terutama perempuan yang berstatus sebagai istri 
nelayan. Istri nelayan selain bekerja aktif dalam urusan domestik atau kaitannya dengan pekerjaan rumah tangga, mereka juga tetap menjalankan fungsi-fungsi ekonomi baik dalam kegiatan penangkapan di perairan dangkal seperti beachseine, kegiatan pengolahan ikan maupun kegiatan jasa dan perdagangan, namun hal ini berbeda dengan aktivitas yang dilakukan oleh istri-istri nelayan buruh di Desa Pengambengan. Mayoritas istri-istri nelayan buruh di Desa Pengambengan hanya menjalankan aktivitas ekonomi dalam bidang pengolahan ikan, jasa dan perdagangan. Istri-istri nelayan buruh banyak memanfaatkan sumberdaya yang tersedia di darat dan tidak terdapat perempuan atau istri nelayan yang melakukan penangkapan ikan di laut atau di perairan, karena memiliki banyak resiko. Berikut merupakan bagan dan dari intensifikasi dan ekstensifikasi yang tidak dilakukan oleh istri-istri nelayan buruh di Desa Pengambengan:

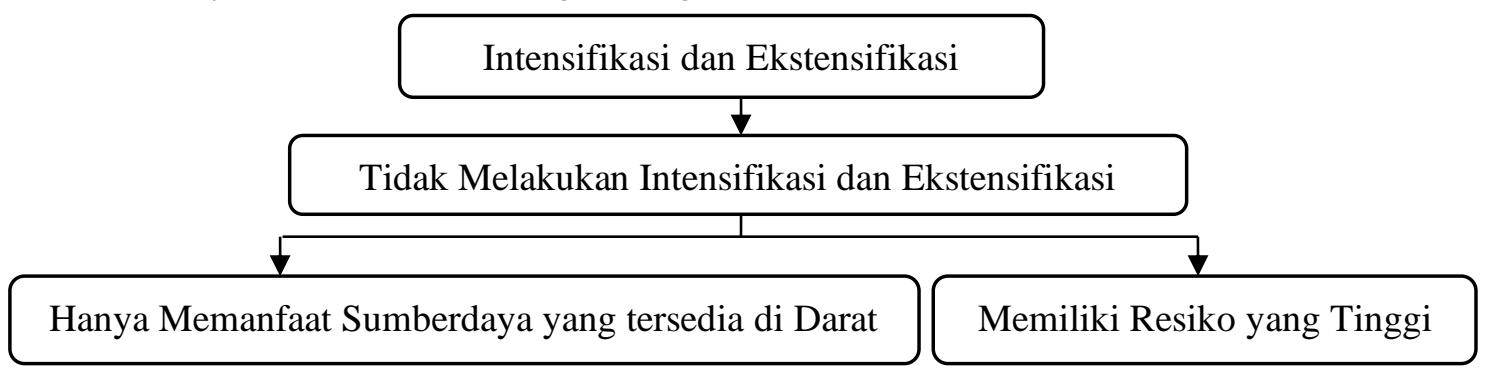

Gambar 5. Bagan Intensifikasi dan Ekstensifikasi Istri Nelayan Buruh di Desa Pengambengan

Intensifikasi dan ekstensifikasi pertanian hanya dapat dilakukan oleh suami atau nelayan buruh. Intensifikasi dan ekstensifikasi pertanian tersebut dilakukan dengan cara memanfaatkan ketersediaan sumberdaya yang terdapat di laut. Nelayan buruh melakukan intensifikasi pertanian yaitu dengan menggunakan perahu kecil (perahu sampan dan perahu fiber) dan melakukan penangkapan ikan dengan jenis yang berbeda. Kegiatan ekstensifikasi tersebut dilakukan dengan cara memancing ikan dan pekerjaan tersebut sebagian besar hanya dilakukan oleh nelayan juru panggung dan nelayan juru mudi yang memiliki perahu fiber atau perahu sampan, karena mereka memiliki modal ekonomi atau finansial yang mencukupi. Hal ini dapat terlihat dari segi penghasilan yang diperoleh juru panggug atau juru mudi yang memiliki penghasilan lebih besar dibandingkan dengan nelayan buruh lainnya, sehingga mereka dapat mengelola modal finansial yang dimiliki secara optimal.

\section{b. Diversifikasi Nafkah atau Matapencaharian}

Istri-istri nelayan buruh di Desa Pengambengan melakukan diversifikasi nafkah atau matapencaharian dengan melakukan berbagai pekerjaan. Berikut merupakan bagan mengenai bentuk diversifikasi nafkah yang dilakukan oleh istri nelayan buruh di Desa Pengambengan:

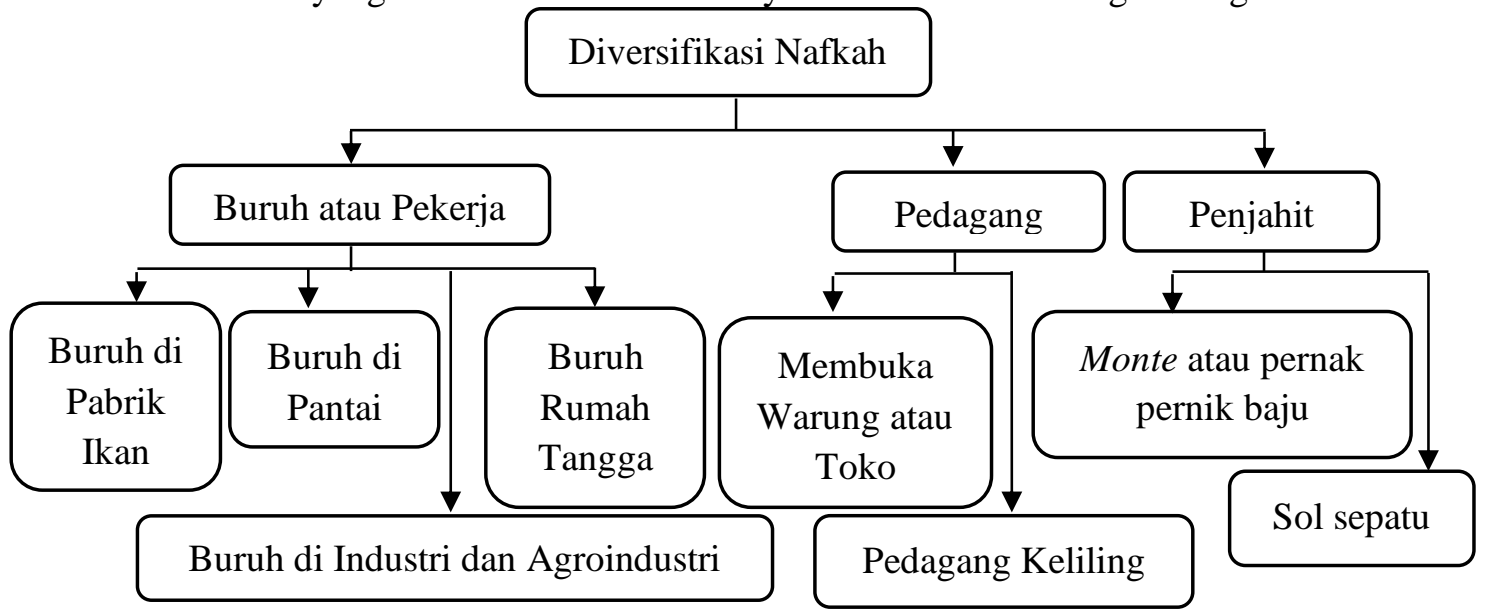

Gambar 6. Bagan Diversifikasi Nafkah Istri Nelayan Buruh di Desa Pengambengan

1) Buruh atau Pekerja

a) Buruh di Pabrik Ikan.

Bekerja sebagai buruh di pabrik ikan merupakan pekerjaan yang sebagian besar dilakukan oleh istri-istri nelayan buruh di Desa Pengambengan. Bekerja sebagai tenaga buruh di pabrik ikan 
dilakukan karena di wilayah Desa Pengambengan terdapat banyak industri yang bergerak dalam bidang pengolahan ikan seperti pabrik pengalengan ikan, pabrik Cold Storage atau pabrik tempat penyimpanan ikan dan pabrik penepungan ikan. Pekerjaan sebagai buruh di pabrik ikan dilakukan dengan sistem borongan dan memperoleh upah harian. Upah yang diperoleh dalam satu hari kerja adalah sebesar Rp15.000-Rp50.000/hari disesuaikan berdasarkan jumlah ikan yang tersedia di pabrik, selain mendapatkan upah harian, terdapat juga istri nelayan buruh yang mendapatkan upah mingguan dengan pabrik ikan yang berbeda. Sistem pembayaran upah di pabrik diberikan setiap seminggu sekali dan perolehan upah yang didapatkan juga tidak pasti karena disesuai dengan ketersediaan ikan di pabrik.

b) Buruh di Pantai

Istri nelayan buruh selain bekerja sebagai buruh di pabrik ikan, mereka juga bekerja sebagai buruh di pantai untuk pengurus perahu sampan. Pekerjaan megurus perahu dilakukan untuk membantu nelayan-nelayan perahu sampan, dimana mereka bekerja untuk membantu dalam kegiatan membuka ikan dari jaring, membantu membersihkan serta memperbaiki jaring/ngayum. Upah yang diperoleh dengan bekerja sebagai buruh di pantai yaitu sebesar Rp20.000-Rp25.000/hari dan diberikan secara lansung oleh pemilik perahu. Pekerjaan menjadi buruh di pantai tidak hanya membantu dalam hal membuka ikan dari jaring, namun mereka juga membantu nelayan untuk mendorong sampan ketika sampan akan melakukan kegiatan melaut dan ketika perahu sampan akan mendarat. Kegiatan mendorong sampan merupakan kegiatan yang rutin dilakukan oleh wanita-wanita atau istri-istri nelayan dan para nelayan yang hidup di wilayah pesisir pantai Pengambengan. Kegiatan tersebut merupakan bagian dari kewajiban istri nelayan maupun nelayan untuk saling membantu dan tolong menolong sesama nelayan. Upah yang didapatkan dari bekerja sebagai buruh di pantai disesuaikan dari hasil tangkapan ikan serta jenis ikan yang diperoleh, apabila jenis ikan yang diperoleh memiliki harga jual yang tinggi maka upah yang diterima juga besar. Rata-rata penghasilan atau upah yang diperoleh ketika sedang terjadi musim ikan adalah sebesar Rp50.000-Rp100.000/ hari, sedangkan rata-rata penghasilan yang diperoleh ketika hasil tangkapan ikan sedikit yaitu antara Rp20.000-Rp25.000/ hari. Pekerjaan menjadi buruh di pantai juga dilakukan oleh istri nelayan buruh sebagai pengurus perahu slerek. Pekerjaan tersebut dapat dilakukan ketika perahu sampan tidak beroperasi atau tidak melaut karena cuaca yang tidak mendukung akibat adanya angin atau gelombang laut yang tinggi, sehingga bekerja sebagai pengurus perahu besar atau perahu slerek. Pekerjaan tersebut dilakukan untuk memenuhi kebutuhan perahu slerek, seperti mengantarkan bahan bakar.

c) Buruh Agroindustri dan Industri

Istri-istri nelayan buruh juga melakukan diversifikasi nafkah dengan bekerja sebagai buruh bersih-bersih dan buruh pembungkus tempe di agroindustri rumah tangga. Upah yang diperoleh dengan bekerja menjadi buruh bersih-bersih dan pembungkus tempe adalah sebesar Rp25.000/hari. Pekerjaan lainnya juga dilakukan oleh istri nelayan buruh, yaitu bekerja sebagai buruh di industri garam sebagai buruh pengisi garam dan buruh di industri batu bata sebagai buruh pencetak batu bata. Strategi tersebut merupakan strategi pola nafkah ganda yang dilakukan oleh istri nelayan buruh. Pekerjaan sebagai buruh pengisi garam dilakukan dengan sistem borongan dan upah yang diperoleh sebagai buruh pengisi garam memperoleh upah sebesar Rp100.000/ minggu. Besar kecilnya upah yang diperoleh disesuaikan berdasarkan jumlah bungkusan garam yang dipesan, sedangkan upah yang diperoleh dengan bekerja sebagai buruh penyetak batu bata adalah sebesar Rp120.000/ 1.000 bata. Pekerjaan-pekerjaan tersebut dilakukan untuk membantu penghasilan suaminya dalam memenuhi kebutuhan hidup rumah tangga.

d) Buruh Rumah Tangga

Strategi pola nafkah ganda lainnya yang dilakukan oleh istri nelayan buruh yaitu menjadi buruh rumah tangga. Pekerjaan tersebut dilakukan untuk mendapatkan nafkah tambahan dari pada harus berdiam diri dan menganggur di rumah. Buruh rumah tangga merupakan pekerjaan yang meliputi kegiatan bersih-bersih rumah dan menyetrika. Penghasilan yang diperoleh bersifat tidak pasti karena disesuaikan dengan pekerjaan yang dilakukan, namun terkadang mendapatkan upah sebesar Rp15.000-Rp50.000. Terdapat juga istri nelayan buruh yang bekerja sebagai buruh bersih-bersih dan buruh masak di rumah tetangganya. Penghasilan yang diperoleh sebagai buruh bersih-bersih dan buruh memasak adalah sebesar Rp200.000/ minggu, namun pekerjaan tersebut tidak dilakukan setiap hari. Pekerjaan tersebut dilakukan ketika ada panggilan saja atau ketika ada pesanan makanan dari pelanggan lesehan milik tetangganya. Pekerjaan sebagai buruh rumah tangga merupakan bentuk 
strategi nafkah yang diakukan oleh istri nelayan buruh untuk membantu menambah penghasilan suami mereka. Hal ini sesuai dengan hasil penelitian yang dilakukan oleh Hutapea dkk. (2012: 4), istri nelayan dapat membantu suami bekerja dengan melakukan pekerjaan sebagai pembantu rumah tangga.

2) Pedagang

Sebagian besar kegiatan ekonomi yang ditekuni oleh istri-istri nelayan buruh di Desa Pengambengan adalah di sektor perdagangan. Kegiatan perdagangan tersebut mereka lakukan di pinggir pantai ataupun dirumah mereka sendiri. Pekerjaan sebagai pedagang yang dilakukan oleh istriistri nelayan buruh di Desa Pengambengan dilakukan dengan cara membuka toko atau warung. Toko atau warung-warung tersebut menjual beraneka macam kebutuhan seperti kebutuhan rumah tangga, jajanan anak-anak serta hidangan makanan. Kegiatan berdagang yang dilakukan oleh istri-istri nelayan buruh tidak jauh dengan kegiatan domestik atau pekerjaan rumah tangga yang dilakukan sehari-hari seperti memasak dan menyediakan makanan.

Istri-istri nelayan buruh juga menjual kebutuhan dapur seperti minyak goreng, bawang putih dan bawang merah. Terdapat juga istri nelayan buruh yang menjual beraneka ragam buah-buahan, selain itu juga berjualan berbagai macam kebutuhan dapur seperti sayur-sayuran, tahu tempe, daging ayam, bumbu-bumbu dapur serta kebutuhan masak lainnya. Penghasilan yang diperoleh dari hasil kegiatan berdagang di pinggir pantai bersifat tidak pasti, karena disesuaikan berdasarkan ramai atau tidaknya pengunjung pantai. Kegiatan perdagangan merupakan salah satu bentuk aktualisasi perempuan nelayan dalam kegiatan perekonomian. Kusnadi dkk. (2006: 46), memaparkan bahwa disamping bekerja dengan menjualkan hasil tangkapan ikan yang diperoleh suaminya, istri-istri nelayan juga membuka warung di pinggir pantai. Sebagian besar konsumen dari warung-warung di pinggir pantai adalah para nelayan yang akan berangkat melaut, dan warung-warung tersebut merupakan tempat persinggahan para nelayan.

Istri-istri nelayan buruh selain membuka warung kecil-kecilan di pinggir pantai, terdapat juga istri nelayan buruh yang membuka warung di samping rumahnya berupa bangunan toko permanen atau tetap. Kegiatan perdagangan lainnya juga dilakukan oleh istri nelayan buruh dengan cara berkeliling yaitu menjual berbagai macam barang. Barang-barang tersebut diantaranya adalah jajanjajan lebaran, baju atau pakaian dan alat-alat kecantikan. Hal ini sesuai dengan hasil penelitian yang dilakukan oleh Hardiansyah (2016: 4) yaitu pekerjaan sampingan yang ditekuni oleh istri nelayan meliputi pekerjaan sebagai pedagang keliling, berjualan sayur, berdagang dirumah dan ada juga yang bekerja sebagai penjahit. Berbagai bentuk pekerjaan yang dilakukan oleh istri nelayan buruh merupakan tindakan mereka untuk mengatasi permasalahan ekonomi dalam rumah tangganya.

3) Penjahit

Pekerjaan menjahit yang ditekuni oleh istri-istri nelayan buruh di Desa Pengambengan adalah menjahit monte. Menjahit monte merupakan pekerjaan sehari-hari yang dilakukan oleh istri nelayan buruh di Desa Pengambengan untuk memanfaat keterampilannya dan mengisi waktu luang agar tidak menganggur di rumah. Pekerjaan sebagai penjahit monte dilakukan agar mereka lebih produktif dalam bekerja walaupun penghasilan yang diperoleh tidak banyak, namun pekerjaan ini mampu memberikan kontribusi untuk menambah penghasilan dalam rumah tangga. Menjahit monte merupakan pekerjaan yang dilakukan dengan cara memasang monte untuk hiasan baju atau tas dengan sistem borongan. Penghasilan yang diperoleh adalah sebesar Rp10.000-Rp12.000/baju, sedangkan upah yang diperoleh untuk menjahit monte pada tas adalah sebesar Rp7.000/tas yang dijahit. Besar kecilnya upah yang diperoleh dari bekerja sebagai penjahit disesuaikan berdasarkan tingkat kesulitan yang dikerjakan.

\section{c. Migrasi}

Strategi nafkah yang dilakukan oleh istri nelayan buruh selain melakukan diversifikasi nafkah, mereka juga melakukan strategi nafkah dengan cara melakukan migrasi. Strategi nafkah dengan melakukan migrasi sesuai dengan konsep yang dikemukakan oleh Scoones (1998: 9), yang menjelaskan bahwa migrasi merupakan strategi nafkah yang dilakukan dengan cara melakukan perpindahan ke suatu daerah tertentu. Strategi dengan cara migrasi dilakukan ketika sumberdaya yang terdapat di desa tidak mampu memberikan manfaat yang cukup bagi istri-istri nelayan buruh. Berikut merupakan bagan strategi nafkah dengan migrasi yang dilakukan oleh istri-istri nelayan buruh di Desa Pengambengan. 


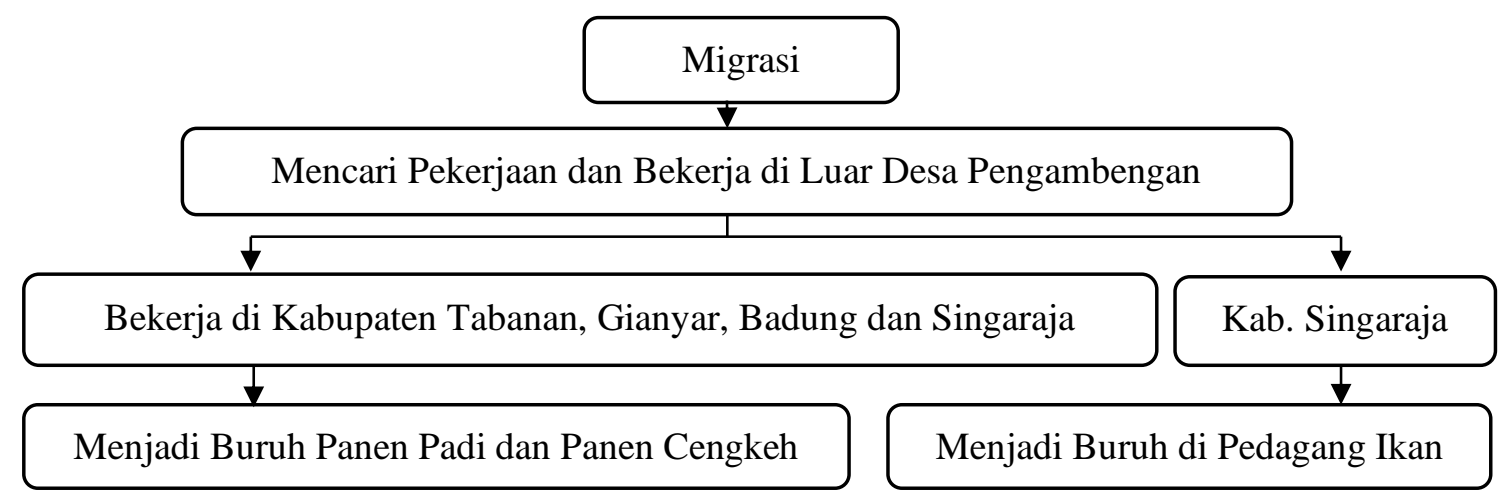

Gambar 7. Bagan Strategi Nafkah dengan Migrasi yang dilakukan oleh Istri Nelayan Buruh di Desa Pengambengan

Strategi migrasi merupakan jalan akhir yang dilakukan oleh istri-istri nelayan buruh ketika di desa sudah tidak memberikan peluang pekerjaan bagi mereka. Migrasi yang dilakukan oleh istri nelayan buruh yaitu dengan cara bekerja di luar daerah Kabupaten Jembrana seperti Kabupaten Tabanan, Kabupaten Gianyar, Kabupaten Badung dan Kabupaten Singaraja. Kegiatan migrasi tersebut mereka lakukan untuk memperoleh nafkah dengan bekerja sebagai buruh tani yaitu sebagai buruh pemotong padi dan buruh panen cengkeh. Pekerjaan tersebut mereka lakukan karena pekerjaan di Desa Pengambengan sulit didapatkan sehingga mereka lebih memilih untuk melakukan migrasi atau memilih bekerja di luar Desa Pengambengan. Strategi nafkah dengan melakukan kegiatan migrasi jarang dilakukan oleh istri-istri nelayan buruh di Desa Pengambengan, karena strategi nafkah dengan melakukan kegiatan migrasi hanya dilakukan ketika sedang terjadi musim sepi ikan. Kegiatan migrasi yang dilakukan oleh istri-istri nelayan buruh merupakan migrasi temporer dimana menurut Lubis (2019: 245), migrasi temporer merupakan migrasi yang dilakukan untuk mencoba mencari peruntungan dengan cara merantau ke luar daerah atau bahkan keluar negeri.

\section{KESIMPULAN}

Motivasi istri nelayan buruh di Desa Pengambengan melakukan pekerjaan di sektor publik adalah kebutuhan fisiologis yaitu untuk memenuhi kebutuhan makan dan minum serta untuk menambah penghasilan berupa gaji atau upah guna memenuhi kebutuhan sehari-hari. Kebutuhan rasa aman yaitu untuk memenuhi kebutuhan saving atau menabung guna mengantisipati ketidakpastian penghasilan yang diperoleh suami atau nelayan buruh. Kebutuhan sosial yaitu berupa keikutsertaan istri nelayan buruh dalam berbagai kegiatan sosial dan kegiatan keagamaan, seperti kegiatan gotong royong, arisan, pengajian dan wiridan. Kebutuhan penghargaan dan kebutuhan aktualisasi diri bukan merupakan motivasi istri nelayan buruh di Desa Pengambengan untuk melakukan pekerjaan di sektor publik. Sumber-sumber nafkah yang dimiliki oleh istri nelayan buruh di Desa Pengambengan terdapat 3 modal, diantaranya adalah modal alam yaitu pemanfaatan jasa lingkungan berupa pemanfaatan pesisir pantai untuk kegiatan bekerja dan melakukan kegiatan perdagangan, pemanfaatan hasil laut berupa ikan untuk dijual dan dikonsumsi sehari-hari. Modal ekonomi yaitu ketersediaan finansial berupa uang tunai, tabungan dan kepemilikan warung, serta kepemilikan infrastruktur dasar berupa bangunan toko sebagai sarana untuk melakukan kegiatan perdagangan. Modal manusia berupa keterampilan, kemampuan fisik, dan kesehatan. Modal sosial berupa hubungan sosial, jaringan kerja, hubungan kepercayaan dan asosiasi. Strategi nafkah yang dilakukan oleh istri nelayan buruh dalam mencukupi kebutuhan hidup rumah tangga di Desa Pengambengan terdiri atas diversifikasi nafkah atau matapencaharian yaitu bekerja sebagai buruh di pabrik ikan, buruh di pantai, buruh agroindustri tempe, buruh di industri bata dan kayu, buruh rumah tangga, pedagang warung dan toko serta bekerja sebagai penjahit. Migrasi yaitu bekerja sebagai buruh atau pekerja di luar Desa Pengambengan seperti bekerja di Kabupaten Tabanan, Kabupaten Gianyar, Kabupaten Badung dan Kabupaten Singaraja.

\section{DAFTAR PUSTAKA}

Badu, M. 2015. Peranan Perempuan Dalam Meningkatkan Kesejahteraan Keluarga Nelayan Di Desa Boyantongo Kecamatan Parigi Selatan Kabupaten Parigi Moutong. Administratie, 01(04):7. 
DFID. 1999. Sustaineable Livelihoods Guidance Sheets. London: Departement for International Development.

Dharmawan, A. H. 2007. Sistem Penghidupan dan Nafkah Pedesaan: Pandangan Sosiologi Nafkah (Livelihood Strategy) Mazhab Bogor. Solidarity: Jurnal Transdisiplin Sosiologi, Komunikasi, dan Ekologi Manusia, 01(02): 170-192.

Goble, F. G. 1971. The Third Force, The Psychology of Abraham Maslow Terjemahan oleh Supratinya, A. 1987. Mazhab Ketiga Psikologi Humanistik Abraham Maslow. Yogyakarta: Kanisius.

Granovetter, M. 1985. Economic Action and Social Structure: The Problem of Embeddedness. American Journal of Sociology, 91(3): 481-510.

Hamdani, H., \& Wulandari, K. 2016. Faktor Penyebab Kemiskinan Nelayan Tradisional (The Factor of Proverty Causes Traditional Fisherman). E-Sospol, 3(1): 62-67.

Hardiansyah, Rila. 2016. Peran Kelompok Perempuan dalam Perberdayaan Kehidupan Sosial Ekonomi Masyarakat Nelayan. Transformasi, 2(2): 1-16.

Helmi, A., dan A. Satria. 2012. Strategi Adaptasi Nelayan terhadap Perubahan Ekologis. Makara, Sosial Humaniora, 16(1): 68-78.

Robbins S. P. dan T. A. Judge. 2008. Perilaku Organisasi Organizational Behavior. Jakarta: Salemba Empat.

Kadir, N. S. 2016. Stretgi Nafkah Keluarga Nelayan Pamekkang di Kelurahan Mamunyu Kabupaten Mamuju. Commercium Kajian Masyarakat Kontemporer, 1(2): 70-80.

Kementrian Kelautan dan Perikanan Republik Indonesia. 2020. Peta Prakiraan Daerah Penangkapan Ikan. https://kkp.go.id/artikel/17999-informasi-peta-prakiraan-daerah-penangkapan-ikan-ppdpiperiode-tanggal-13-15-maret-2020. [Diakses pada 14 Maret 2020].

Kimbal, R. W. 2015. Modal Sosial dan Ekonomi Industri Kecil Sebuah Studi Kualitatif. Yogyakarta: Deepublish.

Kusnadi, H. Sulistiyowati, Sumarjono, dan A. Prasodjo. 2006. Perempuan Pesisir. Yogyakarta: LkiS Yogyakarta.

Kusnadi. 2002. Konflik Sosial Nelayan Kemiskinan dan Perebutan Sumberdaya Perikanan. Yogyakarta: LkiS Yogyakarta.

Laila, N. E. N. 2015. Strategi nafkah perempuan nelayan terhadap pendapatan keluarga. institut pertanian bogor.

Lubis, R. H. 2019. Spiritualitas Bencana: Konteks Pengetahuan Lokal dalam Penanggulangan Bencana. Depok: LKPS.

Mangkunegara, A. P. 2009. Manajemen Sumberdaya Manusia Perusahaan. Bandung: PT. Remaja Rosdakarya.

Marini, I. A. K. dan N. S. K. Ningsing. 2015. Ragam Aktivitas Wanita Nelayan terhadap Peningkatan Pendapatan Rumah Tangga Nelayan di Kota Mataram. Ganec Swara, 9(1): 53-59

Maslow, A. H. 1943. A Theory of Human Motivations. Psychological Review, 50(4): 370-396.

Pemerintahan Kabupaten Jembrana. 2020. RTRW Kabupaten Jembrana 2012-2032 Perda No. 11 Tahun 2012. https://jembranakab.go.id/index.php?module=rtrw. [Diakses pada 14 Maret 2020].

Pratiwi, P. A., A. H. Yani, dan Nofrizal. 2015. Studi Daerah Penangkapan Ikan di Peraitan Sungai Kampar Kanan, Desa Kampung Panjang Kecamatan Kampar Timur Kabupaten Kampar Provinsi Riau. Journal of Management Of Aquatic Resource, 2(2): 1-9.

Priansa, S. dan D. J. 2016. Manajemen SDM dalam Organisasi Publik dan Bisnis. Bandung: Alfabeta. Purnawanto, B. 2010. Manajemen Sumber Daya Manusia Berbasis Proses. Jakarta: Grasindo. 
Rostiyati, A. 2018. Peran Ganda Perempuan Nelayan di Desa Muara Gading Mas Lampung Timur. Patanjala, 187-202.

Satria, A. 2015. Pengantar Sosiologi Masyarakat Pesisir. Jakarta: fakultas ekologi manusia IPB dengan yayassan pustaka obor indonesia.

Scoones, I. 1998. Sustainable Rural Livelihood: A Framework for Analysis. IDS Working Paper No. 72. Institute of Development Studies, University of Sussex, Brighton.

Septiana, Ardelia. 2017. Analisis Pendapatan dan Nilai Tambah Usaha Pembesaran Ikan Gurami di Desa Pliken Kecamatan Kembaran Kabupaten Banyumas. Skripsi. Yogyakarta: Fakultas Pertanian Universitas Gadjah Mada.

Simanjuntak, B. A., H. Hasyim, A. W. Turnip, J. Purba, dan E. K. Siahaan. 1979. Sistim Gotong Royong dalam Masyarakat Pedesaan Daerah Sumatra Utara. Jakarta: Direktorat Jenderal Kebudayaan.

Statistik PPN Pengambengan. 2017. Laporan Statistik Perikanan Tangkap 2017. Negara: Pelabuhan Perikanan Nusantara Pengambengan.

Statistik PPN Pengambengan. 2018. Data Kapal Perikanan PPN Pengambengan (Aktif). Negara: Pelabuhan Perikanan Nusantara Pengambengan.

Sumarti, Titik. 2010. Secercah Cahaya Menuju Kesejahteraan Perempuan. Bogor, Kementerian Sosial RI, Direktorat Jenderal Pemberdayaan Sosial, Direktorat Pemberdayaan Keluarga.

Wisana, I. D. G. K. 2001. Kesehatan sebagai Suatu Investasi. Ekonomi dan Pembangunan Indonesia, 1(1): 42-51. 